\title{
Estimation of the epidemiological burden of human papillomavirus-related cancers and non- malignant diseases in men in Europe: a review
}

\author{
Susanne Hartwig ${ }^{1 *}$, Stina Syrjänen², Géraldine Dominiak-Felden', Maria Brotons ${ }^{3}$ and Xavier Castellsagué ${ }^{3,4}$
}

\begin{abstract}
Background: The role of human papillomavirus (HPV) in malignant and non-malignant genital diseases in women is well known and the corresponding epidemiological burden has been widely described. However, less is known about the role of HPV in anal, penile and head and neck cancer, and the burden of malignant and non-malignant HPV-related diseases in men. The objective of this review is to estimate the epidemiological burden of HPV-related cancers and non-malignant diseases in men in Europe.
\end{abstract}

Methods: The annual number of new HPV-related cancers in men in Europe was estimated using Eurostat population data and applying cancer incidence rates published by the International Agency for Research on Cancer. The number of cancer cases attributable to HPV, and specifically to HPV16/18, was calculated based on the most relevant prevalence estimates. The annual number of new cases of genital warts was calculated from the most robust European studies; and latest HPV6/11 prevalence estimates were then applied. A literature review was also performed to retrieve exhaustive data on HPV infection at all anatomical sites under study, as well as incidence and prevalence of external genital warts, recurrent respiratory papillomatosis and HPV-related cancer trends in men in Europe.

Results: A total of 72, 694 new cancer cases at HPV-related anatomical sites were estimated to occur each year in men in Europe. 17,403 of these cancer cases could be attributable to HPV, with 15,497 of them specifically attributable to HPV16/18. In addition, between 286,682 and 325,722 new cases of genital warts attributable to HPV6/11were estimated to occur annually in men in Europe.

Conclusions: The overall estimated epidemiological burden of HPV-related cancers and non-malignant diseases is high in men in Europe. Approximately 30\% of all new cancer cases attributable to HPV16/18 that occur yearly in Europe were estimated to occur in men. As in women, the vast majority of HPV-positive cancer in men is related to HPV16/18, while almost all HPV-related non-malignant diseases are due to HPV6/11. A substantial number of these malignant and non-malignant diseases may potentially be prevented by quadrivalent HPV vaccination.

Keywords: HPV, Epidemiology, Cancer, Genital warts, Condylomata acuminata, Men, Europe

\section{Background}

Human papillomavirus (HPV) has been established as a necessary cause of cervical cancer. Around $50 \%$ of women become infected with HPV by age 20-30 years [1] and persistent infection can lead to the development of malignant and non-malignant diseases. Indeed, the role of HPV in cervical cancer, in premalignant lesions

\footnotetext{
* Correspondence: shartwig@spmsd.com

'Department of Epidemiology, Sanofi Pasteur MSD, Lyon, France

Full list of author information is available at the end of the article
}

of the cervix, vulva and vagina, and in external genital warts is well known, and the corresponding epidemiological burden in women has been widely described [2-6]. However, less is known about the natural history of HPV infection in men and the role of HPV in penile, anal and head and neck cancers.

As early as 1983, it was suggested that a subset of cancers of the oral cavity and larynx may be caused by HPV [7]. The juxtaposition between the squamous cell epithelium and the lymphatic tissue in the oropharynx,

\section{Biomed Central}

(c) 2011 Hartwig et al; licensee BioMed Central Ltd.. This is an Open Access article distributed under the terms of the Creative Commons Attribution License (http://creativecommons.org/licenses/by/2.0), which permits unrestricted use, distribution, and reproduction in any medium, provided the original work is properly cited. 
as well as the transformation zone of the anal canal, share similarities with the transformation zone of the cervix, and might therefore be areas that are highly susceptible to HPV infection.

In 2007 the International Agency for Research on Cancer (IARC) concluded that there was "sufficient" evidence to support the carcinogenicity of HPV in the penis, anus, oral cavity, oropharynx and tonsils, and "limited" evidence to support the carcinogenicity of HPV in the larynx [8]. This statement was confirmed by an IARC Monograph Working Group in 2011 [9].

In addition to cancer, HPV is responsible for some non-malignant diseases. Indeed, the great majority of genital warts, recurrent respiratory papillomatosis and oral papillomas are attributable to HPV, mostly HPV6/ 11 [10-12].

All HPV-induced cancers and non-malignant diseases are necessarily preceded by HPV infection. However, little is known about the prevalence of HPV infection and related diseases in men at different anatomical sites. Therefore the purpose of this review is to estimate the epidemiological burden of HPV-related cancers and non-malignant diseases, as well as the prevalence of $\mathrm{HPV}$ infection, in men in Europe.

\section{Methods}

\section{Literature review}

A literature review was performed to retrieve exhaustive European data on trends of HPV-related cancers, incidence and prevalence of genital warts, recurrent respiratory papillomatosis and HPV infection. Searches were conducted on MEDLINE and included articles published from January 1990 through November 2010.

Articles containing data on the trends of HPVrelated cancers were obtained by combining the search terms "HPV", "human papillomavirus", "cancers" and "trends". Those with data on the prevalence and incidence of genital warts and recurrent respiratory papillomatosis were obtained by using different combinations of the following search terms "genital warts", "anogenital warts", "external warts", "condyloma/condylomata acuminata", "incidence" and "prevalence"; and "papillomatosis", "incidence" and "prevalence", respectively. Finally, articles containing data on the incidence and prevalence of HPV infections were obtained by combining the search terms "HPV", "human papillomavirus", "infection", "oral cavity”, “oropharynx”, "larynx”, "anus”, "penis”, "men” and "males".

Only articles referring to the populations of the 26 European countries included in this review were considered. Articles identified from the reference lists of retrieved publications were also included.

\section{Estimation of the annual number of new cancer cases}

For the purposes of this review, cancers occurring at three anatomical sites were considered HPV-related, as HPV infection may play a role in their development: a subset of head and neck cancers (International Classification of Diseases $10^{\text {th }}$ Revision (ICD-10) codes C01C02, C03-C06, C09, C10, C12, C13, C14 and C32, (Table 1)), anal cancer (C21) and penile cancer (C60). All epidemiological cancer data described in this review refer exclusively to these selected cancers and cancer sites, which are hereafter referred to as "HPV-related".

To estimate the mean annual number of new HPVrelated cancer cases in men in Europe, sex- and agespecific annual cancer incidence rates by country, extracted from Volume IX of the Cancer Incidence in Five Continents (CI5) database, were applied to the respective Eurostat country male population estimates [13]. The age-specific estimated numbers of new male cancer cases were summed up to obtain the overall number of expected cases in 2008 for each selected country:

$$
\sum_{0}^{85+} n b \text { of new cases } 2008=\frac{A I R *(\text { per } 100,000) \times \text { population } * *(2008)}{100,000}
$$

*age- and sex-specific annual incidence rate

**age- and sex-specific population

The expected numbers of new cancer cases of all selected countries were then summed up to estimate the overall European Burden.

The number of cancer cases that may have been attributable to HPV and specifically to HPV16/18 was then evaluated by applying cancer-specific HPV prevalence and HPV16/18 prevalence estimates, respectively, extracted from the most relevant published data. When available, European data were used. When European data were not available, worldwide data were used.

For comparison purposes, the same methods were also used to estimate the epidemiological burden of HPVrelated cancers in women in Europe. HPV-related cancer sites in women are the cervix uteri (ICD-10 code C53), vagina (C52), vulva (C51), anus (C21) and a subset of head and neck cancers (C01-C02, C03-C06, C09, C10, C12, C13, C14 and C32).

The CI5 database, available on the IARC website [14], contains worldwide data on cancer incidence rates by ICD-10 codes, obtained from cancer registries that meet the IARC's quality criteria [15]. The registries are either regional or national, depending on the country. The data included in Volume IX were collected between 1998 and 2002.

Only cancer registries that meet the IARC's quality criteria, i.e., that have reliable national or regional cancer registry data, are included in the CI5 database. We 
Table 1 List of included head and neck sites and subsites

\begin{tabular}{ll}
\hline Site description & ICD-10 Code \\
\hline Oral cavity & C01-C02 \\
\hline Tongue (incl. base of the tongue, other parts of the tongue) & C03-C06 \\
\hline Mouth (incl. gum, floor of the mouth, palate) & \\
\hline Pharynx & C09 \\
\hline Tonsil & C10 \\
\hline Oropharynx & C12 \\
\hline Piriform sinus & C13 \\
\hline Hypopharynx & C14 \\
\hline Pharynx unspecified (incl. Waldeyer's ring, overlapping lesion of lip, oral cavity and pharynx) & C32
\end{tabular}

selected all European Union countries. Four of them (Greece, Hungary, Luxemburg, and Romania) were not included in the CI5 database as they did not have reliable registry data. Three European countries (Iceland, Norway and Switzerland) that do not belong to the European Union were also selected as they are located in the same geographical area and share similarities in terms of way of life. Hence a total of 26 European countries were included in this analysis.

Information in the CI5 database originated from national cancer registries for Austria, Bulgaria, Cyprus, the Czech Republic, Denmark, Estonia, Finland, Iceland, Ireland, Latvia, Lithuania, Malta, the Netherlands, Norway, Slovenia, Slovakia and Sweden. Regional cancer registry data were available for Belgium, France, Germany, Italy, Poland, Portugal, Spain, Switzerland and the United Kingdom.

To ensure that national populations were adequately represented in countries where only regional cancer registries exist, the geographical coverage and distribution of these registries was assessed.

\section{Estimation of the annual number of new cases of genital warts}

To estimate the annual number of incident cases of genital warts, two European publications which provided, based on their design, the most robust incidence data for Europe, were selected [16,17]: both are retrospective cohort studies carried out in databases, including very large samples of routinely collected data. We extrapolated the value from each publication to all 26 European countries to provide a range of estimated new cases of genital warts that are expected to occur yearly in men in Europe. The German incidence data [17] were used to estimate the lower value, and the data from the United Kingdom [16] the upper value. The estimated prevalence of HPV6/11 in genital warts was then applied based on the only two European publications identified on the subject $[10,12]$.
For comparison purposes the same method was used to estimate the epidemiological burden of HPV-related genital warts in women in Europe.

\section{Results}

HPV-related cancers

Head and neck cancers

Head and neck cancers generally first occur between 30 and 35 years of age among men in Europe. The incidence then steadily increases with a peak in the sixth decade of life for oropharyngeal cancer and cancer of the oral cavity, and in the seventh decade of life for laryngeal cancer (Figure 1).

The overall age-standardised incidence rates of the subset of head and neck cancers included in this review, irrespective of HPV status, ranged from 5.6 (in Cyprus) to 33.0 (in France) per 100,000 man-years in Europe (CI5 Volume IX) (Figure 2). They were characterised by a strong incidence gradient, with rates increasing from 5.6 to 8.2 per 100,000 man-years in Cyprus and the Nordic countries (Sweden, Finland, Norway and Iceland) up to $27.0-33.0$ per 100,000 man-years in Spain, the Slovak Republic and France.

Among the included subset of head and neck cancers, laryngeal cancer had the highest incidence in Europe (age-standardised incidence rates ranging from 2.0 per

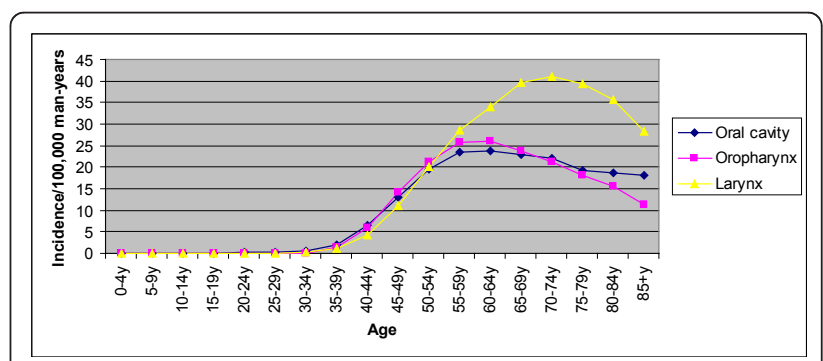

Figure 1 Incidence of head and neck cancers, irrespective of HPV status, in men in Europe by age group. 


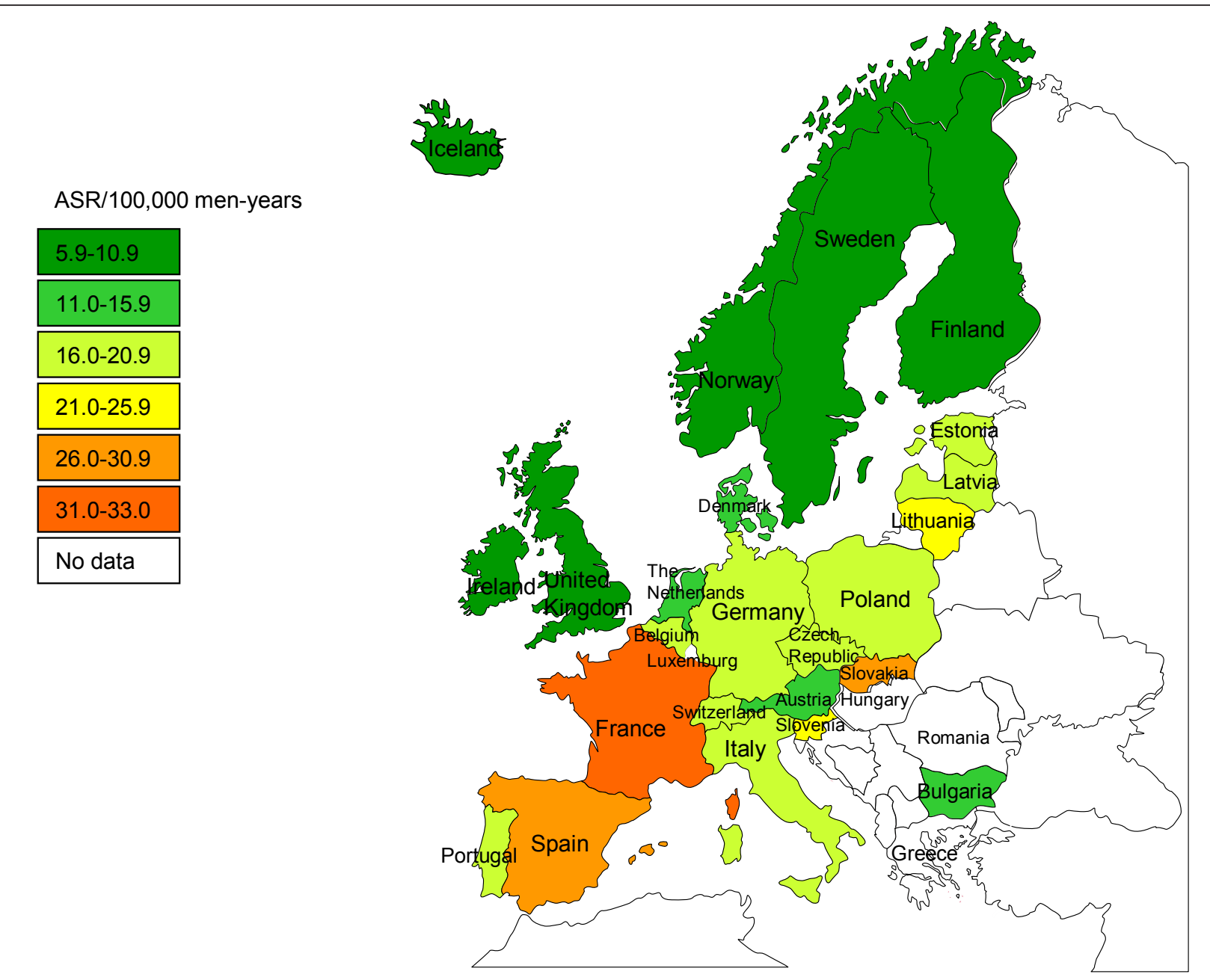

Figure 2 Age-standardised incidence rate (ASR) of a subset of head and neck cancers irrespective of human papillomavirus status.

100,000 man-years in Sweden to 13.3 per 100,000 manyears in Spain), higher than that of cancer of the oral cavity (1.8 per 100,000 man-years in Cyprus to 10.7 per 100,000 man-years in France) and oropharynx (0.6 per 100,000 man-years in Cyprus to 14.1 per 100,000 manyears in France).

Moreover, the incidence of cancer at different head and neck sites did vary by geographical region. For example, cancer of the oral cavity was predominant in the Nordic countries, while oropharyngeal cancer was most common in Western and Central European countries (France, Germany, Switzerland, Austria, Slovenia and Slovakia). In the remaining European countries, laryngeal cancer was the most common, with incidence rates representing up to $50 \%$ of head and neck cancers in several countries (Bulgaria, Poland, Italy, Spain, Malta) (Figure 3a-c).

Within the included subset of head and neck cancers, a total of 67,354 (bounds: 63,443-71,292) new cases were estimated to occur in men in Europe every year (cancer of the oral cavity: 20,133 cases, oropharyngeal cancer: 20,433 cases, laryngeal cancer: 26,788 cases). Assuming an HPV prevalence of $16.0 \%$ for cancer of the oral cavity, $28.2 \%$ for oropharyngeal cancer (except hypopharyngeal cancer where HPV prevalence is the same as for laryngeal cancer) and $21.3 \%$ for laryngeal cancer [18], a total of 14,098 (bounds: 11,455-17,077) of these cases would actually be attributable to $\operatorname{HPV}(3,221$ cancers of the oral cavity, 5,171 oropharyngeal cancers and 5,706 laryngeal cancers) (Table 2).

HPV16/18 are the predominant types in HPV-positive head and neck cancers. They are thought to be present in $68.2 \%$ and $34.1 \%$, respectively, of HPV-positive cancers of the oral cavity, $86.7 \%$ and $2.8 \%$ of HPV-positive oropharyngeal cancers and $69.2 \%$ and $17.0 \%$ of HPVpositive laryngeal cancers [18]. Accordingly, a total of 12,707 new head and neck cancer cases were expected to be attributable to HPV16/18 each year in men in 

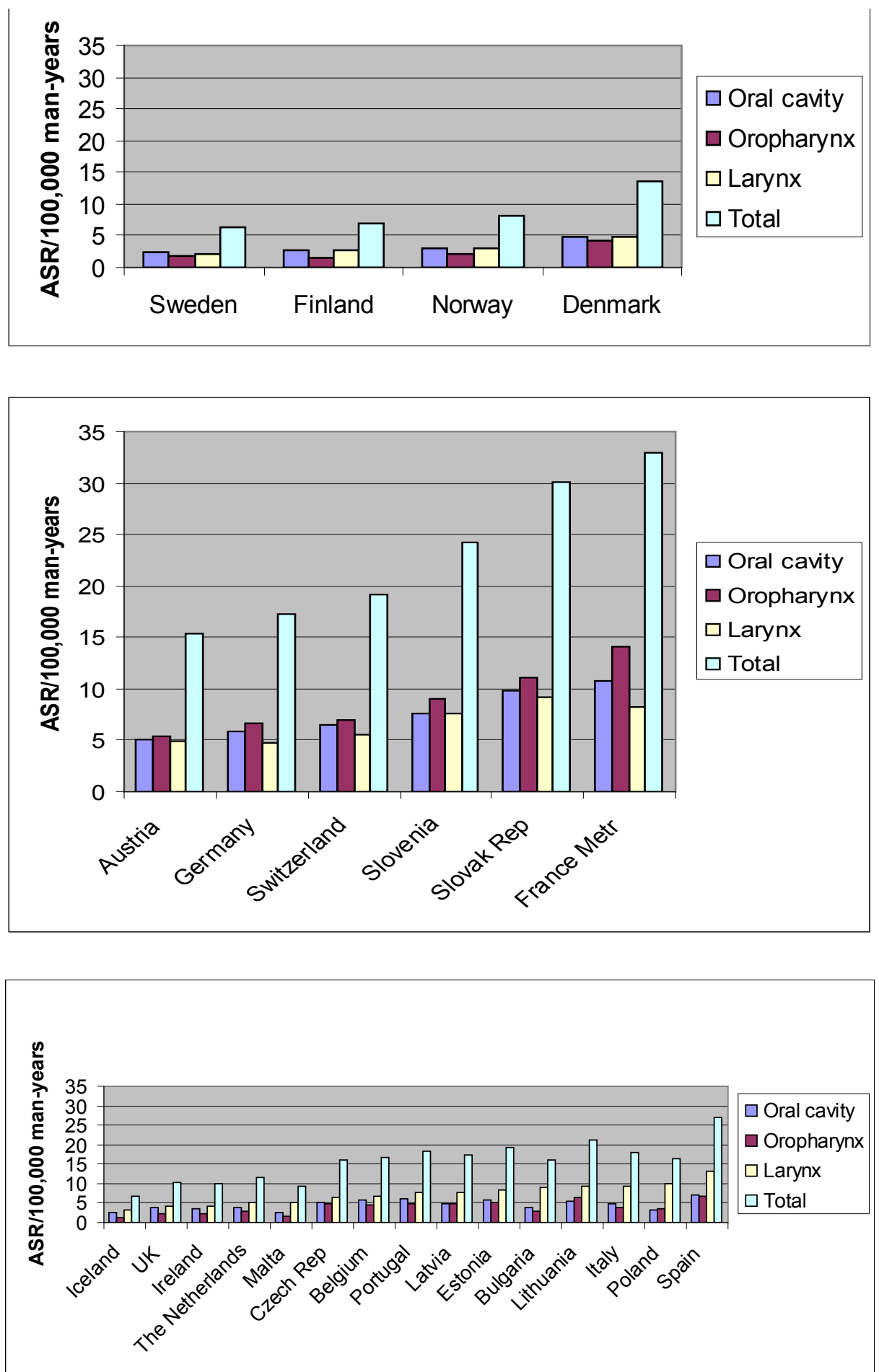

Figure 3 Distribution of head and neck cancers by anatomical site in men in Europe. a. Distribution of head and neck cancers by anatomical site in men in countries where cancer of the oral cavity is predominant. b. Distribution of head and neck cancers by anatomical site in countries where oropharyngeal cancer is predominant. c. Distribution of head and neck cancers by anatomical site in countries where laryngeal cancer is predominant. ASR age standardised incidence rate. 
Table 2 Expected annual number of new human papillomavirus (HPV)-related cancer cases in men in Europe ${ }^{\text {a }}$

\begin{tabular}{|c|c|c|c|c|c|}
\hline $\begin{array}{l}\text { Cancer sites } \\
\text { (ICD } 10 \\
\text { code) }\end{array}$ & $\begin{array}{l}\text { Expected number of new } \\
\text { cancer cases, irrespective of } \\
\text { HPV status } \\
\text { (bounds) }\end{array}$ & $\begin{array}{l}\text { HPV } \\
\text { prevalence } \\
\text { by site }(\%) \\
(95 \% \mathrm{Cl})\end{array}$ & $\begin{array}{l}\text { Expected number of } \\
\text { new cancer cases } \\
\text { attributable to HPV } \\
\text { (bounds) }\end{array}$ & $\begin{array}{c}\text { Prevalence of HPV 16/ } \\
18 \text { in HPV-positive } \\
\text { cancers (\%) }\end{array}$ & $\begin{array}{c}\text { Expected number of new } \\
\text { cancer cases attributable } \\
\text { to HPV16/18 }\end{array}$ \\
\hline $\begin{array}{l}\text { Head and } \\
\text { neck } \\
\text { Oral cavity } \\
\text { Oropharynx } \\
\text { Larynx (C32) }\end{array}$ & $\begin{array}{c}67,354 \\
(63,443-71,292) \\
20,133 \\
(18,768-21,514) \\
20,433 \\
(19,651-21,776) \\
26,788 \\
(25,210-28,382)\end{array}$ & $\begin{array}{c}16.0 \\
(13.4-18.8) \\
28.2^{d} \\
(24.4-32.2) \\
21.3 \\
(18.5-24.3) \\
{[18]}\end{array}$ & $\begin{array}{c}14,098 \\
(11,455-17,077) \\
3,221 \\
(2,515-4,045) \\
5,171 \\
(5030-5311) \\
5,706 \\
(4,664-6,897)\end{array}$ & $\begin{array}{c}68.2 / 34.1 \\
86.7 / 2.8 \\
69.2 / 17.0\end{array}$ & $\begin{array}{l}\frac{12,707}{3,221} \\
4,567 \\
4,919\end{array}$ \\
\hline Anus (C21) & $\begin{array}{c}2,162 \\
(1,722-2,620)\end{array}$ & $\begin{array}{c}84.2 \\
(81.5-86.9) \\
{[19]}\end{array}$ & $\begin{array}{c}1,821 \\
(1,403-2,277)\end{array}$ & $87.1 / 6.2$ & 1,699 \\
\hline Penis (C60) & $\begin{array}{c}3,178 \\
(2,623-3,751)\end{array}$ & $\begin{array}{c}46.7 \\
(42.0-51.3) \\
{[20]}\end{array}$ & $\begin{array}{c}1,484 \\
(1,102-1925)\end{array}$ & $60.2 / 13.4$ & 1,091 \\
\hline Total & $\begin{array}{c}72,694 \\
(67,957-77,470)\end{array}$ & & $\begin{array}{c}17,403 \\
(14,049-21,161)\end{array}$ & & 15,497 \\
\hline
\end{tabular}

Europe $(3,221$ cancers of the oral cavity, 4,567 oropharyngeal cancers and 4,919 laryngeal cancers) (Table 2).

Three European studies reported an increasing incidence trend in the included subset of head and neck cancers in men. In the United Kingdom, the incidence of squamous cell carcinoma of the oral cavity and oropharynx in men rose by $51 \%$ between 1989 and 2006 [21]. In Sweden, an increase of $2.6 \%$ in the incidence of tonsillar cancer in men was observed in each year between 1960 and 2003 [22,23].

\section{Anal cancer}

Anal cancer generally first occurs between 30 and 35 years of age among men in Europe. The incidence then steadily increases with age in all European countries (data not shown). Age-standardised rates of anal cancer ranged from 0.2 (in Cyprus, Finland and Iceland) to 0.7 per 100,000 man-years (in the United Kingdom) (CI5 Volume IX) (Figure 4).

A total of 2,162 (bounds: 1,722-2,620) new anal cancer cases were estimated to occur each year in men in Europe, irrespective of HPV status. Given the overall HPV prevalence of $84.2 \%$ (95\%CI: $81.5 \%-86.9 \%$ ) [19] in anal cancer, 1,821 (bounds: $1,403-2,277$ ) cases in men in Europe were estimated to be attributable to HPV. The prevalence of HPV16/18 in HPV positive anal cancer cases has been estimated at $87.1 \%$ and $6.2 \%$ respectively [19]. After applying this prevalence, 1,699 of cases were estimated to be attributable to HPV16/18 (Table 2).

Several studies have reported an increasing trend in the incidence of anal cancer in men in Europe over time. In Southeast England the age-standardised incidence rates in men increased from 0.79 per 100,000 man-years in 1960-1964 to 1.06 in 2000-2004. The Scottish Cancer Registry recorded an increase in the agestandardised incidence rates of anal squamous cell carcinoma in men, from 0.14 per 100,000 man-years in the late 1970 s to 0.37 in the late 1990 s, with a peak of 0.44 in 1993-1997 [24]. Similar trends have been seen in other European countries: in Denmark, the annual incidence rates in men rose from 0.25 per 100,000 manyears in $1958-1962$ to 0.38 in $1983-1987$ according to Frisch et al. [25] and the age standardised incidence rate of anal cancer in men increased from 0.45 per 100,000 man-years in 1978-1982 to 0.80 in 2003-2008 according to Nielsen et al. [26]. In Sweden, Goldman et al. [27] recorded an annual increase of $4.6 \%$ in incidence rates among men, from 0.52 per 100,000 man-years in 1970 1974 to 0.84 in $1980-1984$. Increasing trends have also been reported from the Netherlands [28].

\section{Penile cancer}

In Europe, penile cancer tends to be diagnosed at age 30-35 years onwards, with an incidence peak in the seventh decade of life (data not shown). Age-standardised rates of penile cancer in men in Europe, irrespective of HPV status, ranged between 0.5 (in Finland) and 1.1 per 100,000 man-years (in Denmark, Portugal and Iceland) (CI5 Vol. IX) with substantial geographical variations (Figure 5).

A total of 3,178 (bounds: 2,623-3,751) new penile cancer cases were estimated to occur annually in Europe. 


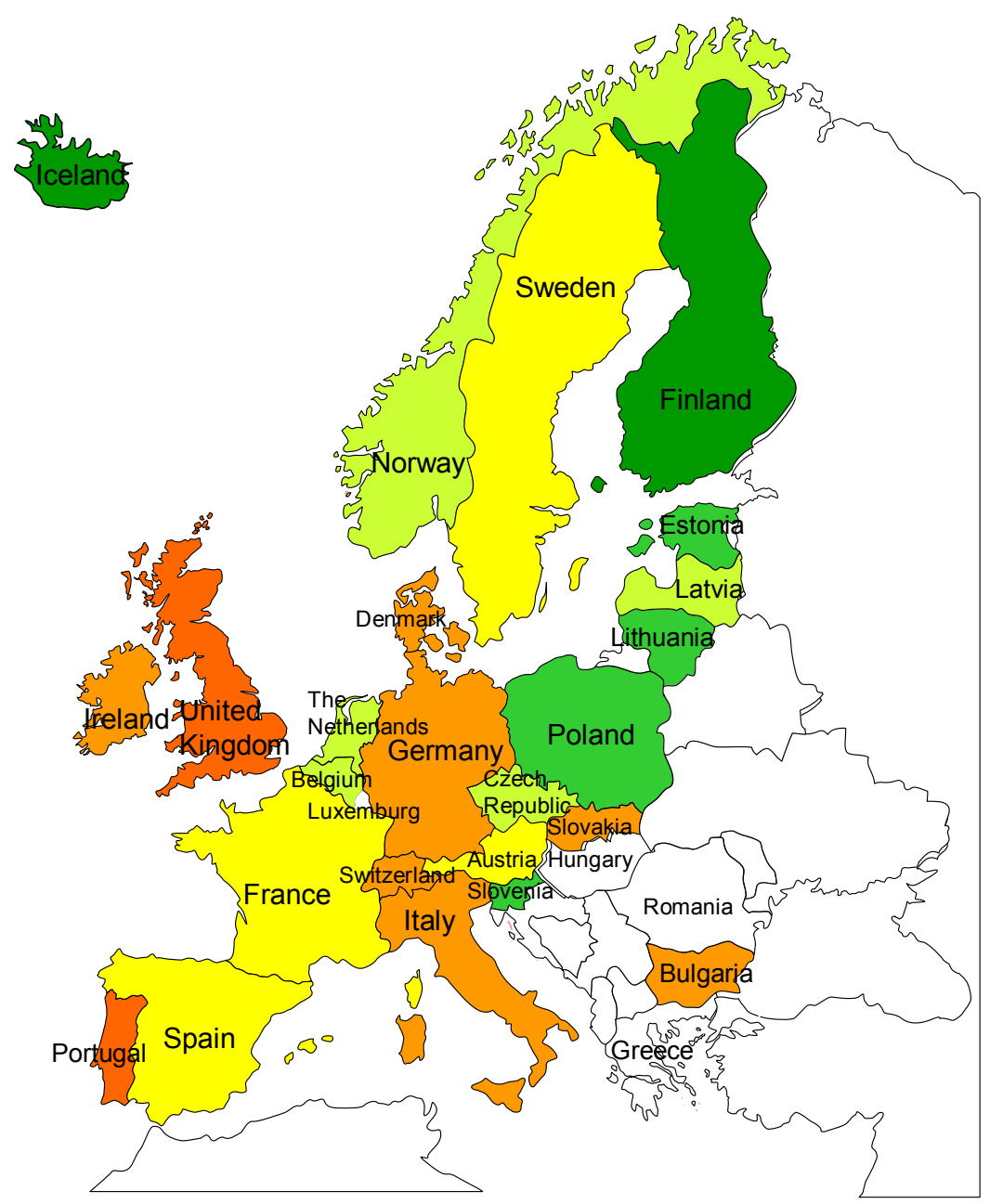

Figure 4 Age-standardised incidence rate (ASR) of anal cancer irrespective of human papillomavirus status in men in Europe.

Assuming an overall HPV prevalence of 46.7\% (95\%CI: 42.0\%-51.3\%) and a specific HPV16/18 prevalence of $60.2 \%$ and $13.4 \%$ respectively among HPV-positive cancers [20], 1,484 (bounds: 1,102-1,925) penile cancer cases were estimated to be attributable to HPV, with 1,091 of those specifically attributable to HPV16/18 (Table 2).

Increasing trends have been reported in the Netherlands, where one study noted a significant increase in the 3-year moving average incidence rate of penile squamous cell carcinoma between 1989 and 2006, with an estimated annual percentage of change of $1.3 \%$ [29].

\section{HPV-related non-malignant diseases Genital warts}

Genital warts represent a non-malignant disease affecting anogenital sites. In men genital warts may occur on the penis, anus, urethra, perianal skin and scrotum. Most reports in the scientific literature did not indicate the exact localisation of warts, and instead combined all localisations into one group.

Prevalence Three studies provided data on the prevalence of genital warts in the general male population in Europe [30-32]. The lowest prevalence was reported in Spain $(0.2 \%)$ [30], while the highest numbers were recorded in a cohort of 432 Finnish conscripts (5.6\%) [31] (Table 3).

Other studies evaluated the prevalence of genital warts in high-risk populations [37-40]. Prevalence ranged from $2.5 \%$ in male sex partners of women with cervical intraepithelial neoplasia (CIN) in the Netherlands [37], to $58 \%$ among men who have sex with men (MSM) in Greece [38] (Table 4).

Incidence Six studies [16,17,30,33,34,36] provided incidence data of new cases for men in Europe, ranging from 136 per 100,000 man-years in Spain [30] to 294 per 100,000 man-years in Sweden [36]. When 


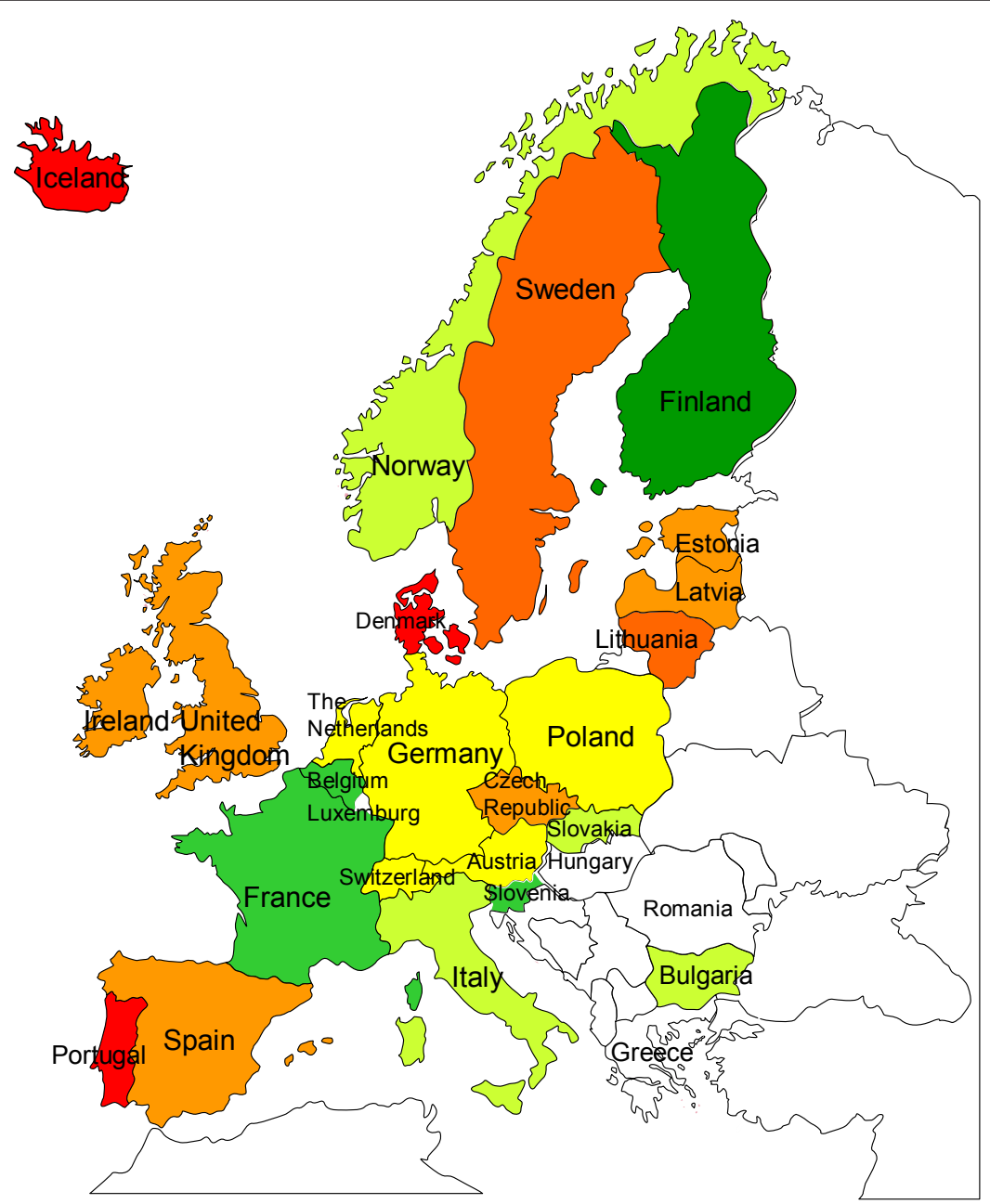

ASR/100,000 men-years

\begin{tabular}{|l|}
\hline 0.5 \\
\hline 0.6 \\
\hline \hline 0.7 \\
\hline \hline 0.8 \\
\hline \hline 0.9 \\
\hline 1.0 \\
\hline 1.1 \\
\hline \hline No data \\
\hline
\end{tabular}

considering new and recurrent cases incidence rates could even reach 319 per 100,000 man-years [33,34].

The most robust data on the incidence of genital warts come from Germany [17] and the United Kingdom [16]: Based on these studies, a lower incidence estimate of 147.6 per 100,000 man-years and an upper estimate of 167.7 per 100,000 man-years were extracted, and so new annual genital wart cases in men in Europe were estimated to range between 335,301 and 380,961. Assuming an HPV6/11 prevalence in genital warts of $85.5 \%[10,12]$, between 286,682 and 325,722 of these cases were estimated to be attributable to HPV6/11.

Recent data on genital warts rates seen at GUM clinics are available at Health Protection Agency webpage: the incidence of genital warts in men increased from 148.5 per 100,000 in 2006 to 160.5 per 100,000 in 2010 [41].

\section{Recurrent respiratory papillomatosis}

European data on the incidence of recurrent respiratory papillomatosis are very scarce. The only available data were reported from Denmark where two studies reported similar incidence rates: 0.38 cases per 100,000 for the period 1968-1984 [42] and 0.35 per 100,000 for the period 1974-1999 [43]. However there was no information about sex-specific incidence.

\section{HPV infection}

HPV infection in the oral cavity and oropharynx

Five European studies provided data about the prevalence of oral cavity and oropharyngeal HPV infections in men. Three of them measured the prevalence of all HPV types in the oral mucosa of cancer-free men. Eike et al. [44] and Van Dornuum et al. [45] found a prevalence of $0 \%$ in the oral mucosa of almost 100 men, while in the Finnish Family Study prevalence was 18\% among 131 husbands of 
Table 3 Studies reporting on the incidence and prevalence of genital warts in general male populations in Europe ${ }^{a}$

\begin{tabular}{|c|c|c|c|c|c|c|c|}
\hline $\begin{array}{l}\text { Author, year, } \\
\text { country }\end{array}$ & Population & $\begin{array}{l}\text { Sample } \\
\text { size }\end{array}$ & Design & Incidence/100,000 & $95 \% \mathrm{Cl}$ & $\begin{array}{c}\text { Prevalence } \\
(\%)\end{array}$ & $\begin{array}{c}95 \% \\
\mathrm{Cl}\end{array}$ \\
\hline $\begin{array}{l}\text { Castellsagué, } 2010 \\
\text { Spain [30] }\end{array}$ & General & & $\begin{array}{l}\text { Retrospective } \\
\text { (medical } \\
\text { records) }\end{array}$ & 136 & & 0.2 & \\
\hline $\begin{array}{c}\text { Simms, } 1997 \\
\text { UK [33] }\end{array}$ & GUM clinic attendees & & Prospective & $\begin{array}{c}\text { First occurence }+ \text { recurrent } \\
\text { cases } \\
65(1971) \\
319(1994)\end{array}$ & & ND & \\
\hline $\begin{array}{l}\text { Cassell, } 2006 \\
\text { UK [34] }\end{array}$ & $\begin{array}{c}\text { General practice + GUM clinic } \\
\text { attendees }\end{array}$ & & $\begin{array}{l}\text { Retrospective } \\
\text { cohort }\end{array}$ & $\begin{array}{c}\text { First occurence }+ \text { recurrent } \\
\text { cases } 307.6\end{array}$ & $\begin{array}{l}(305.5- \\
309.8)\end{array}$ & ND & \\
\hline $\begin{array}{l}\text { Kraut, } 2010 \\
\text { Germany [17] }\end{array}$ & & $\stackrel{>}{>}$ & $\begin{array}{l}\text { Retrospective } \\
\text { cohort }\end{array}$ & $\begin{array}{l}144.57(2005) \\
147.95(2006)\end{array}$ & $\begin{array}{c}(141.10- \\
148.09) \\
(144.48- \\
151.48)\end{array}$ & ND & \\
\hline $\begin{array}{c}\text { Fenton, } 2001 \\
\text { UK [35] }\end{array}$ & General & 4,500 & Survey & $\begin{array}{l}\text { Cumulative incidence (self } \\
\text { reported) } \\
360\end{array}$ & $(310-420)$ & ND & \\
\hline $\begin{array}{l}\text { Persson, } 1996 \\
\text { Sweden [36] } \\
\end{array}$ & General & 32,774 & Prospective & 294 & $(207-372)$ & ND & \\
\hline $\begin{array}{l}\text { Hippeläinen, } 1993 \\
\quad \text { Finland [31] }\end{array}$ & Finnish conscripts & 432 & Cross-sectional & ND & & 5.6 & $\begin{array}{l}(3.4- \\
7.7) \\
\end{array}$ \\
\hline $\begin{array}{l}\text { Kataoka, } 1991 \\
\text { Sweden [32] }\end{array}$ & Sweden & 108 & Cross-sectional & ND & & 1.9 & $\begin{array}{l}(0- \\
4.4)\end{array}$ \\
\hline $\begin{array}{l}\text { Desai, } 2011 \\
\quad \text { UK [16] }\end{array}$ & $\begin{array}{c}\text { General practice + GUM clinic } \\
\text { attendees }\end{array}$ & & $\begin{array}{l}\text { Retrospective } \\
\text { cohort }\end{array}$ & 168 & & ND & \\
\hline
\end{tabular}

Cl confidence interval, GUM Genitourinary medicine, ND no data

a 26 European countries

pregnant women tested with nested PCR [46]. The two remaining studies evaluated high-risk HPV prevalence and found a $3.8 \%$ prevalence in 26 healthy adult volunteers, from whom samples had been taken at three different sites of the oral cavity [47], and $14.5 \%$ in the saliva of 69 male odonto-stomatology attendees without oral pathologies, aged 4-77 years [48]. In all studies HPV detection was carried out by PCR (Table 5).

\section{Anal HPV infection}

Six European studies analysed the prevalence of anal HPV infections. All included cancer-free subjects belonging to presumed high-risk groups for HPV infection, such as MSM, HIV-positive men, sexually-transmitted disease (STD) clinic attendees and heterosexual men with multiple sexual partners. The overall prevalence of anal HPV infection in these high-risk groups ranged between $15.3 \%$ in a sample of 85 male STD clinic attendees [49] and 94.1\% among 17 HIV-positive MSM [49]. Anal HPV prevalence in HIV-positive MSM and HIVpositive heterosexual men ranged from $64.7 \%$ [40] to $94.1 \%$ [50] and $46,0 \%$ [51] to $68.2 \%$ [52], respectively. HPV prevalence in HIV-negative MSM was evaluated in one study to be $32.8 \%$ [40] (Table 6).

\section{Penile HPV infection}

Twenty-three European studies provided information on the prevalence of penile HPV infections in more

Table 4 Studies reporting on the prevalence of genital warts in high-risk male populations in Europe ${ }^{\text {a }}$

\begin{tabular}{|c|c|c|c|c|c|}
\hline Author & Country & Population & Design & Prevalence (\%) & $95 \% \mathrm{Cl}$ \\
\hline Kyriakis, 2005 [38] & Greece & $\begin{array}{c}3667 \mathrm{HS} \\
856 \mathrm{MSM} \\
211 \mathrm{IDU}(\mathrm{HS}+\mathrm{MSM})\end{array}$ & Cross-sectional, hospital based & $\begin{array}{c}53 \mathrm{HS} \\
58 \mathrm{MSM} \\
51 \mathrm{IDU}\end{array}$ & $\begin{array}{l}(51.4-54.6) \\
(55.1-61.7) \\
(44.0-57.4)\end{array}$ \\
\hline Van der Snoek, 2003 [40] & The Netherlands & $\begin{array}{l}258 \mathrm{MSM} \\
241 \mathrm{HIV}- \\
17 \mathrm{HIV+}\end{array}$ & Cross-sectional & 27 & $(21.6-32.4)$ \\
\hline Bleeker, 2002 [37] & The Netherlands & 119 male sex partners of women with CIN & Prospective & 2,5 & $(0.31-5.30)$ \\
\hline Svare, 2002 [39] & Denmark & 261 STD clinic attendees & Prospective & 25 & $(19.7-30.1)$ \\
\hline
\end{tabular}

HS heterosexual, MSM men who have sex with men, IDU intravenous drug user, CI confidence interval, CIN cervical intraepithelial neoplasia, STD sexually transmitted disease

a 26 European countries 
Table 5 Studies reporting head and neck human papillomavirus (HPV) infection in cancer-free men in Europe ${ }^{a}$

\begin{tabular}{|c|c|c|c|c|c|c|c|c|c|}
\hline \multirow{2}{*}{$\begin{array}{l}\text { Author, } \\
\text { year, } \\
\text { country }\end{array}$} & \multirow[t]{2}{*}{ Sample types } & \multirow[t]{2}{*}{ Population } & \multirow{2}{*}{$\begin{array}{l}\text { Sample } \\
\text { size }\end{array}$} & \multirow{2}{*}{$\begin{array}{c}\text { Age } \\
\text { (years) }\end{array}$} & \multirow{2}{*}{$\begin{array}{l}\text { Sampling techniques and } \\
\text { detection methods }\end{array}$} & \multicolumn{4}{|c|}{ HPV (\%) } \\
\hline & & & & & & Any & $\begin{array}{l}95 \% \\
\mathrm{Cl}\end{array}$ & $\begin{array}{l}\text { High- } \\
\text { risk }\end{array}$ & $\begin{array}{c}95 \% \\
\mathrm{Cl} \\
\end{array}$ \\
\hline $\begin{array}{l}\text { Montaldo } \\
2007 \\
\text { Italy [48] }\end{array}$ & Saliva & $\begin{array}{l}\text { Odonto- } \\
\text { stomatology attendees, non- } \\
\text { diseased for oral pathology }\end{array}$ & 69 & $4-77$ & $\begin{array}{l}\text { Specimen } \\
\text { PCR }\end{array}$ & ND & & 14.5 & $\begin{array}{l}(7.17- \\
25.04)\end{array}$ \\
\hline $\begin{array}{l}\text { Kujan } 2006 \\
\text { UK [47] }\end{array}$ & $\begin{array}{l}\text { Three different sites } \\
\text { in the oral cavity }\end{array}$ & Healthy volunteers & 26 & $>18$ & $\begin{array}{l}\text { Brushing } \\
\text { PCR }\end{array}$ & ND & & 3.8 & $\begin{array}{l}(0.10- \\
19.64)\end{array}$ \\
\hline $\begin{array}{l}\text { Rintala } 2005 \\
\text { Finland [46] }\end{array}$ & Oral mucosa & $\begin{array}{l}\text { Husbands of pregnant women } \\
\text { (Finnish Family Study) }\end{array}$ & 131 & & $\begin{array}{l}\text { Brushing } \\
\text { nested PCR }\end{array}$ & 18 & $\begin{array}{l}(11.5- \\
24.5)\end{array}$ & & \\
\hline $\begin{array}{l}\text { Eike } 1995 \\
\text { Denmark [44] }\end{array}$ & Oral mucosa & $\begin{array}{l}\text { Patients with unrelated diseases } \\
\text { and their relatives }\end{array}$ & 31 & $20-79$ & $\begin{array}{l}\text { Smear } \\
\text { PCR }\end{array}$ & 0 & & 0 & \\
\hline $\begin{array}{l}\text { Van } \\
\text { Doornum, } \\
1992[45]\end{array}$ & $\begin{array}{l}\text { Tongue and buccal } \\
\text { mucosa }\end{array}$ & $\begin{array}{l}\text { Men with multiple heterosexual } \\
\text { partners }\end{array}$ & 65 & $\begin{array}{l}\text { mean } \\
\text { age: } 38\end{array}$ & $\begin{array}{l}\text { Swabs } \\
\text { PCR }\end{array}$ & 0 & & 0 & \\
\hline
\end{tabular}

$N D$ no data, $\mathrm{Cl}$ confidence interval

a 26 European countries

than 4,300 men. The majority of the study subjects belonged to high-risk groups (HIV-positive men, MSM, partners of women with CIN and STD clinic attendees). The overall HPV prevalence ranged from $2.2 \%$ (95\% CI: 0-6.4) in the semen of 46 husbands of women with HPV-related genital lesions [53], to $72.9 \%$ (95\% CI: 65.8-79.3) in a report on male partners of women with CIN [54].

One study [55], including 947 men with HPV-related lesions or HPV-positive partners, compared samples at different anatomical sites of the penis as well as semen samples. HPV prevalence was highest on the penile shaft $(58.3 \%)$, followed by the glans/corona (43.3\%), urethra $(31.0 \%)$ and semen $(23.9 \%)$ (Table 7$)$.

\section{Discussion}

Using different data sources and extrapolation methods, this review showed that the overall estimated epidemiological burden of HPV-related cancers and non-malignant diseases is high among men in Europe. In addition to malignant diseases, which include a subset of head and neck cancers and anal and penile cancers, nonmalignant diseases such as genital warts and recurrent respiratory papillomatosis are also associated with HPV.

Table 6 Studies reporting anal human papillomavirus (HPV) infection in cancer-free men in Europe ${ }^{a}$

\begin{tabular}{|c|c|c|c|c|c|c|}
\hline \multirow[t]{2}{*}{ Author, year } & \multirow[t]{2}{*}{ Country } & \multirow[t]{2}{*}{ Population } & \multirow[t]{2}{*}{ Sample size } & \multirow{2}{*}{$\begin{array}{l}\text { Sampling techniques and } \\
\text { detection methods }\end{array}$} & \multicolumn{2}{|c|}{ HPV (\%) } \\
\hline & & & & & Any & $95 \% \mathrm{Cl}$ \\
\hline $\begin{array}{l}\text { Van der Snoek, } \\
2003 \text { [40] }\end{array}$ & $\begin{array}{l}\text { The } \\
\text { Netherlands }\end{array}$ & $\begin{array}{c}\text { MSM } \\
\text { HIV+ and HIV- }\end{array}$ & $\begin{array}{c}258 \\
(17 \text { HIV+, } 241 \\
\text { HIV-) }\end{array}$ & $\begin{array}{c}\text { Swabs } \\
P C R+\text { LiPA }\end{array}$ & $\begin{array}{l}64.7(\mathrm{HIV+}) \\
32.8(\mathrm{HIV}-)\end{array}$ & $\begin{array}{l}(38.33-85.79) \\
(27.06-38.94)\end{array}$ \\
\hline $\begin{array}{l}\text { Pierangeli, } 2008 \\
\text { [56] }\end{array}$ & Italy & $\begin{array}{c}\text { MSM and } \\
\text { HS (HIV+ and HIV-) }\end{array}$ & $\begin{array}{c}61 \\
(36 \mathrm{HIV}+, \\
25 \mathrm{HIV}-)^{\prime}\end{array}$ & $\begin{array}{l}\text { Anal brushing } \\
\text { PCR }\end{array}$ & $\begin{array}{l}81.6(\mathrm{HIV+}) \\
68.0(\mathrm{HIV-})\end{array}$ & $\begin{array}{l}(63.98-91.81) \\
(46.50-85.05)\end{array}$ \\
\hline Sirera, 2006 [52] & Spain & $\begin{array}{l}\text { HIV+ men } \\
\text { (MSM and HS) }\end{array}$ & $\begin{array}{c}74 \\
(52 \mathrm{MSM} \\
22 \mathrm{HS})\end{array}$ & $\begin{array}{l}\text { Cytobrush } \\
\text { PCR }\end{array}$ & $\begin{array}{l}82.6(\mathrm{MSM}) \\
68.2(\mathrm{HS})\end{array}$ & $\begin{array}{l}(69.67-91.77) \\
(45.13-86.14)\end{array}$ \\
\hline Piketty, 2003 [51] & France & $\begin{array}{c}\text { HIV+ men } \\
\text { (MSM and HSiDU) }\end{array}$ & $\begin{array}{c}118 \\
\text { (67 MSM, } 50 \\
\text { HSiDU) }\end{array}$ & $\begin{array}{l}\text { Swabs } \\
\text { PCR }\end{array}$ & $\begin{array}{l}85.1 \text { (MSM) } \\
46.0 \text { (HSiDU) }\end{array}$ & $\begin{array}{l}(74.26-92.60) \\
(31.81-60.68)\end{array}$ \\
\hline $\begin{array}{l}\text { Van Doornum, } \\
1994 \text { [49] }\end{array}$ & $\begin{array}{l}\text { The } \\
\text { Netherlands }\end{array}$ & STD clinic attendees & 85 & Cotton swabs or wooden spatula & 15.3 & $(8.40-24.73)$ \\
\hline $\begin{array}{l}\text { Löwhagen, } 1999 \\
\text { [50] }\end{array}$ & Sweden & $\begin{array}{c}\text { STD clinic attendees (HIV+ } \\
\text { and HIV- MSM) }\end{array}$ & $\begin{array}{c}30 \\
(17 \text { HIV+, } \\
13 \text { HIV-) }\end{array}$ & $\begin{array}{l}\text { Cotton swabs } \\
\text { PCR }\end{array}$ & $\begin{array}{c}76.7 \\
94.1 \text { (HIV+) } \\
53.8 \text { (HIV-) }\end{array}$ & $\begin{array}{c}(61.5-91.8) \\
(82.9-100.0) \\
(26.7-80.9)\end{array}$ \\
\hline
\end{tabular}

CI confidence interval, MSM men who have sex with men, STD sexually transmitted disease, HS heterosexual, HSiDU heterosexual intravenous drug user, STD sexually transmitted disease

a 26 European countries 
Table 7 Studies reporting penile human papillomavirus (HPV) infection in cancer-free men in Europe ${ }^{a}$

\begin{tabular}{|c|c|c|c|c|c|c|c|c|c|}
\hline Author & Country & Anatomical site(s) & Population & Sample & & & & (\%) & \\
\hline & & & & & & Any & $95 \% \mathrm{Cl}$ & $\begin{array}{l}\text { High- } \\
\text { risk }\end{array}$ & $95 \% \mathrm{Cl}$ \\
\hline $\begin{array}{l}\text { Bleeker } 2005 \\
\text { [54] }\end{array}$ & $\begin{array}{l}\text { The } \\
\text { Netherlands }\end{array}$ & $\begin{array}{l}\text { Glans, corona, frenulum } \\
\text { and prepuce }\end{array}$ & Partners of women with CIN & 181 & $\begin{array}{l}\text { Cervex brush } \\
\text { GP5+/6+ PCR }\end{array}$ & 72.9 & $(65.8-79.3)$ & 58.5 & $(51.0-79.3)$ \\
\hline $\begin{array}{l}\text { Kjaer } 2005 \\
{[57]}\end{array}$ & Denmark & Glans and corona & Danish soldiers & 337 & $\begin{array}{l}\text { Penile swabs } \\
\text { PCR }\end{array}$ & 33.8 & $(28.8-39.2)$ & & \\
\hline $\begin{array}{l}\text { Sirera } 2006 \\
{[52]}\end{array}$ & Spain & $\begin{array}{l}\text { Coronal sulcus, glans and } \\
\text { urethra distal }\end{array}$ & $\begin{array}{l}\text { HIV+ men } \\
\text { (MSM and HS) }\end{array}$ & $\begin{array}{c}74 \\
(52 \mathrm{MSM} \\
22 \mathrm{HS})\end{array}$ & $\begin{array}{l}\text { Cytobrush } \\
\text { PCR }\end{array}$ & $\begin{array}{c}38 \\
(\mathrm{MSM}) \\
32(\mathrm{HS})\end{array}$ & $\begin{array}{l}(25-53) \\
(14-55)\end{array}$ & & \\
\hline $\begin{array}{l}\text { Van der } \\
\text { Snoek } 2003 \\
\text { [40] }\end{array}$ & $\begin{array}{l}\text { The } \\
\text { Netherlands }\end{array}$ & Coronal sulcus & STD clinic attendees; MSM HIV+ and HIV- & $\begin{array}{c}258 \\
17 \mathrm{HIV+} \\
241 \mathrm{HIV}-\end{array}$ & $\begin{array}{l}\text { Dry swab } \\
P C R+L i P A\end{array}$ & $\begin{array}{c}23.5 \\
(\mathrm{HIV+}) \\
15.8 \\
(\mathrm{HIV}-)\end{array}$ & $\begin{array}{l}(6.81-49.9) \\
(11.4-21.0)\end{array}$ & & \\
\hline $\begin{array}{l}\text { Bleeker } 2002 \\
{[37]}\end{array}$ & $\begin{array}{l}\text { The } \\
\text { Netherlands }\end{array}$ & $\begin{array}{l}\text { Glans, corona, frenulum } \\
\text { and prepuce }\end{array}$ & Partners of women with CIN & 119 & $\begin{array}{l}\text { Cervex brush } \\
\text { GP5 } 5+/ 6+P C R\end{array}$ & 59.0 & $(49.4-67.8)$ & 55.4 & $(46.1-67.8)$ \\
\hline $\begin{array}{l}\text { Svare } 2002 \\
\text { [39] }\end{array}$ & Denmark & $\begin{array}{l}\text { Glans, corona, shaft, } \\
\text { scrotum and perianus }\end{array}$ & STD clinic attendees & 198 & $\begin{array}{l}\text { Scrapping plus pre- } \\
\text { wetted swabs } \\
\text { GP5+/6+ PCR }\end{array}$ & 45.0 & $(37.9-52.2)$ & 18.6 & $(12.5-52.2)$ \\
\hline $\begin{array}{l}\text { Wikstrom } \\
2000[58]\end{array}$ & Sweden & $\begin{array}{l}\text { Glans, corona, shaft, } \\
\text { scrotum and perianus }\end{array}$ & STD clinic attendees & 235 & $\begin{array}{l}\text { Scrapping plus pre- } \\
\text { wetted swabs } \\
\text { GP5+/6+ PCR }\end{array}$ & 20.4 & $(15.3-25.6)$ & 12.8 & $(8.5-17.0)$ \\
\hline $\begin{array}{l}\text { Van } \\
\text { Doornum } \\
1994 \text { [49] }\end{array}$ & $\begin{array}{l}\text { The } \\
\text { Netherlands }\end{array}$ & $\begin{array}{l}\text { Corona, urethra, anus and } \\
\text { rectum }\end{array}$ & HS STD clinic attendees & 85 & $\begin{array}{c}\text { Cotton swab/ } \\
\text { wooden spatula } \\
\text { PCR }\end{array}$ & 28.2 & $(19.0-39.0)$ & & \\
\hline $\begin{array}{l}\text { Forslund } \\
1999[59]\end{array}$ & Sweden & Urethra & Military conscripts and adolescent clinic attendees & 138 & $\begin{array}{l}\text { Prewetted brush } \\
\text { PCR }\end{array}$ & 8.7 & $(4.6-14.7)$ & & \\
\hline $\begin{array}{l}\text { Hippelainen } \\
1993 \text { [31] }\end{array}$ & Finland & $\begin{array}{l}\text { Glans, prepuce, sulcus, } \\
\text { urethral meatus and } \\
\text { urethra }\end{array}$ & Finnish conscripts & 285 & $\begin{array}{l}\text { Prewetted brush } \\
\text { PCR }\end{array}$ & 16.5 & $(12.4-21.3)$ & & \\
\hline $\begin{array}{l}\text { Franceschi } \\
2002[60]\end{array}$ & Spain & $\begin{array}{l}\text { Glans, corona, and } \\
\text { urethra }\end{array}$ & Husbands of women with invasive cervical cancer & 84 & $\begin{array}{l}\text { Cotton tipped } \\
\text { Swabs } \\
\text { PCR }\end{array}$ & 11.9 & $(5.9-20.8)$ & 1.2 & $(0.0-20.8)$ \\
\hline & & & Husbands of women with cervical carcinoma in situ & 102 & & 21.6 & $(14.0-30.8)$ & 6.9 & $(2.8-30.8)$ \\
\hline & & & Husbands of control women & 168 & & 3.6 & $(1.3-7.6)$ & 1.8 & $(0.4-7.6)$ \\
\hline $\begin{array}{l}\text { Wikstrom } \\
1991[58]\end{array}$ & Sweden & $\begin{array}{l}\text { Corona, prepuce, and } \\
\text { urethral meatus }\end{array}$ & $\begin{array}{l}\text { STD clinic attendees, men with no history of genital } \\
\text { warts }\end{array}$ & 135 & PCR & & & 13.3 & $(8.1-59.1)$ \\
\hline
\end{tabular}




\begin{tabular}{|c|c|c|c|c|c|c|c|c|c|}
\hline $\begin{array}{l}\text { Barzon } 2010 \\
{[55]}\end{array}$ & Italy & $\begin{array}{l}\text { Glans/Corona, penile } \\
\text { shaft, urethra }\end{array}$ & $\begin{array}{l}\text { Males presenting for screening for STDs, } \\
\text { investigation of suspected HPV-related lesions, or } \\
\text { because of HPV-positive partners }\end{array}$ & 947 & $\begin{array}{l}\text { Swabs } \\
\text { PCR }\end{array}$ & $\begin{array}{c}\text { Glans/ } \\
\text { corona: } \\
43.3 \\
\text { Penile } \\
\text { shaft: } \\
58.3 \\
\text { Urethra: } \\
31.0 \\
\text { Semen: } \\
23.9\end{array}$ & $\begin{array}{l}(39.0-47,6) \\
(47.8-68.3) \\
(25.6-36.5) \\
(19.0-28.8)\end{array}$ & $\begin{array}{l}12.2 \\
9.4 \\
7.3 \\
5.6\end{array}$ & $\begin{array}{c}(9.32-15.0) \\
(4.38-17.05) \\
(4.2-10.4) \\
(18.9-28.8)\end{array}$ \\
\hline $\begin{array}{l}\text { Kataoka, } \\
1991[32]\end{array}$ & Sweden & Urethra & Army conscripts & 105 & $\begin{array}{l}\text { Brushing } \\
\text { PCR }\end{array}$ & 17.1 & $(9.9-24.4)$ & & \\
\hline $\begin{array}{l}\text { Hillman, } \\
1993[61]\end{array}$ & $\begin{array}{l}\text { United } \\
\text { Kingdom }\end{array}$ & $\begin{array}{l}\text { Urethra } \\
\text { Urine }\end{array}$ & STD clinic attendees & $\begin{array}{l}100 \\
\text { urethra } \\
\text { samples } \\
88 \text { urine } \\
\text { specimen }\end{array}$ & $\begin{array}{l}\text { Cotton-tipped swabs } \\
\text { Urine sample } \\
\text { PCR }\end{array}$ & $\begin{array}{l}\text { Urethra: } \\
18.0 \\
\text { Urine: } \\
12.5\end{array}$ & $\begin{array}{c}(10.5-25.5) \\
(5.6-19.4)\end{array}$ & $\begin{array}{l}\text { Urethra: } \\
\text { 12.0 } \\
\text { Urine: } \\
9.1\end{array}$ & $\begin{array}{l}(5.6-18.4) \\
(3.1-15.1)\end{array}$ \\
\hline $\begin{array}{l}\text { Aynaud, } \\
2002[53] \\
\end{array}$ & France & Semen & $\begin{array}{l}\text { Men with normal peniscopy whose female partners } \\
\text { have genital HPV lesions }\end{array}$ & 46 & $\begin{array}{l}\text { Ejaculate } \\
\text { PCR }\end{array}$ & 2.2 & $(0-6.4)$ & $\mathrm{NI}$ & \\
\hline $\begin{array}{l}\text { Aynaud, } \\
2003[62]\end{array}$ & France & Meatal-urethral smears & $\begin{array}{l}\text { Men with normal peniscopy whose female partners } \\
\text { have genital HPV lesions }\end{array}$ & 34 & $\begin{array}{l}\text { Brushing } \\
\text { PCR }\end{array}$ & 2.9 & $(0-8.4)$ & $\mathrm{Nl}$ & \\
\hline $\begin{array}{l}\text { Giovanelli, } \\
2007[63]\end{array}$ & Italy & $\begin{array}{l}\text { Penile shaft, foreskin, } \\
\text { coronal sulcus, frenulum, } \\
\text { glans, semen }\end{array}$ & Partners of HPV-positive women & 50 & $\begin{array}{l}\text { Cotton-tipped swab, } \\
\text { cytobrush, ejaculate } \\
\text { PCR }\end{array}$ & 72.0 & $(59.6-84.4)$ & 56.0 & $(42.2-69.8)$ \\
\hline $\begin{array}{l}\text { Benevolo, } \\
2008[64]\end{array}$ & Italy & $\begin{array}{l}\text { Penile shaft, prepuce, } \\
\text { coronal sulcus, glans, } \\
\text { distal urethra }\end{array}$ & $\begin{array}{l}\text { Male partners of women with CIN and/or positive } \\
\text { HPV }\end{array}$ & 71 & $\begin{array}{l}\text { Cytobrush } \\
\text { PCR }\end{array}$ & 35.2 & $(24.1-46.3)$ & 31.0 & $(20.2-41.7)$ \\
\hline $\begin{array}{l}\text { Bleeker, } 2004 \\
\text { [65] }\end{array}$ & $\begin{array}{l}\text { The } \\
\text { Netherlands }\end{array}$ & $\begin{array}{l}\text { Glans, corona, sulcus, } \\
\text { frenulum, foreskin }\end{array}$ & $\begin{array}{l}\text { Men with female partners, visiting department of } \\
\text { dermatology for non-STD complaints }\end{array}$ & 83 & $\begin{array}{l}\text { Brushing } \\
\text { PCR }\end{array}$ & 25.3 & $(15.9-34.7)$ & 19.3 & $(10.8-27.8)$ \\
\hline \multirow[t]{2}{*}{$\begin{array}{l}\text { Castellsagué, } \\
1997 \text { [66] } \\
\text { Bosch, } 1996 \\
\text { [67] }\end{array}$} & Spain & $\begin{array}{l}\text { Intrameatal and distal } \\
\text { urethra, glans, coronal } \\
\text { sulcus }\end{array}$ & Male partners of women with cervical cancer & 183 & Cotton-tipped swabs & 17.5 & $(12.0-23.0)$ & 15.8 & $(10.6-21.1)$ \\
\hline & & & Male partners of control women & 171 & & 3.5 & $(0.8-6.3)$ & 2.3 & $(0.1-4.6)$ \\
\hline $\begin{array}{l}\text { Voog, } 1997 \\
{[68]}\end{array}$ & Sweden & Glans penis, prepuce & STD clinic attendees & 20 & Cytobrush & 25 & $(6.0-44.0)$ & $\mathrm{Nl}$ & \\
\hline $\begin{array}{l}\text { Strand, } 1993 \\
\text { [69] }\end{array}$ & Sweden & $\begin{array}{l}\text { Urethra, glans penis, } \\
\text { sulcus, preputium, penile } \\
\text { shaft }\end{array}$ & STD clinic attendees & 65 & $\begin{array}{l}\text { Plastic probe + } \\
\text { cytobrush }\end{array}$ & 29.2 & $(18.2-40.3)$ & $\mathrm{NI}$ & \\
\hline
\end{tabular}

CI confidence interval, CIN cervical intraepithelial neoplasia, MSM men who have sex with men, HS heterosexual, STD sexually transmitted disease

a 26 European countries 
Moreover, the majority of HPV-positive cancers in men are attributable to oncogenic HPV16/18, while the great majority of genital warts and virtually all cases of recurrent respiratory papillomatosis are caused by HPV6/11.

In this report, a total of 72,694 new HPV-related cancer cases were estimated to occur each year in men in Europe. Moreover, we estimated that 17,403 of these cancers could be attributable to HPV, of which 15,497 were estimated to be specifically attributable to HPV16/ 18.

In addition, between 335,301 and 380,961 new cases of genital warts were estimated to occur annually in men in Europe, with 286,682-325,722 of them attributable to HPV6/11.

Recurrent respiratory papillomatosis is a very rare disease and incidence data in Europe are scarce. It was not possible to estimate the number of new annual cases in men in Europe. Nevertheless, the association with HPV is particularly strong for this disease, and virtually all cases are attributable to HPV6/11 [70].

\section{HPV-related cancers \\ Head and neck cancers}

There was high variability in the incidence of head and neck cancers, irrespective of HPV status, with age-standardised incidence rates in Europe ranging from 5.6 to 33.0 per 100,000 man-years. The distribution of the subset of head and neck cancers included herein also varied throughout Europe. This may be partially due to regional differences in HPV prevalence, which are in turn related to differences in the distribution of risk factors for HPV infection, such as sexual behaviour. It may also be due to differences in the distribution of non-HPVrelated risk factors like alcohol consumption and tobacco use, which explain some $80 \%$ of these cancers.

Large cohort studies from Sweden show increasing evidence of a steady rise in the incidence of a subset of cancers of the oral cavity (especially lateral border of the tongue) [71] and oropharynx (notably tonsillar and base of the tongue $[22,23,71,72])$. In these studies oropharyngeal cancer was most strongly associated with HPV. The overall HPV detection rate in tonsillar carcinoma reached up to 51\%, with HPV16 being the most common type (84\%) $[71,73,74]$. The increasing trend may be due to an increase of HPV infections in the head and neck, possibly related to changes in sexual behaviour.

\section{Anal cancer}

An overall number of 2,162 annual cases were estimated to occur in men in Europe, irrespective of HPV status and the association of anal cancer with HPV is extremely strong (84.2\% HPV-related) [19].

An increasing trend in the incidence of anal cancer has been reported for a number of countries, including Denmark [25], Sweden [27], the Netherlands [28] and the United Kingdom [24]. Regional differences in incidence could be explained by regional differences in anal HPV prevalence, the key causal precursor for anal cancer [75], and its associated causes and consequences, such as history of condyloma [76], history of anoreceptive intercourse [76,77] and increased lifetime number of sexual partners [78].

\section{Penile cancer}

Three thousand one hundred seventy-eight new penile cancer cases, irrespective of HPV status, were estimated to occur yearly in Europe with almost half of these cases $(1,484)$ attributable to HPV.

In addition to regional differences in penile HPV prevalence, differences in the incidence of penile cancer may be due to differences in the regional distribution of risk factors that are not related to HPV infection, such as smoking, phimosis and absence of circumcision $[79,80]$.

\section{HPV-related non-malignant diseases Genital warts}

The burden of genital warts in men in Europe is substantial. Extrapolated from the most robust European incidence data collected in Germany and in the United Kingdom, new cases were estimated to range between 335,301 and 380,961 in men in Europe every year. The vast majority are estimated to be attributable to HPV6/ 11. As for HPV-related malignant diseases, the incidence of genital warts varies highly by geographical region. This may be due partially due to differences in the distribution of risk factors for HPV infection. Furthermore, there is some evidence of a steady rise of genital warts in men in the United Kingdom [81].

Genital warts are not life-threatening, but they are associated with high morbidity: psychosocial stigma, psychosexual dysfunction, depression and lower quality of life $[82,83]$. Treatment is painful, and there is a high risk of recurrence.

\section{Recurrent respiratory papillomatosis}

In Europe, only two studies provided data on the incidence of recurrent respiratory papillomatosis in both sexes: $0.35-0.38$ per 100,000 person-years. There was no specific information about incidence in men but the sex ratio for juvenile onset recurrent respiratory papillomatosis was reported to be $1: 1$, while there was a pronounced male preponderance in onset in adulthood [42].

Virtually $100 \%$ of cases are caused by HPV, the most common types being HPV6/11 [11]. Maternal condyloma or genital HPV infection during pregnancy is the overwhelming risk factor for juvenile onset recurrent respiratory papillomatosis (more than 200-fold increased risk) $[43,70]$. Although non-malignant, the disease is associated with very high morbidity. It has the potential 
to be life-threatening and the number of lifetime surgeries may exceed 100 in children with severe disease [70].

\section{HPV infection \\ Head and neck}

Overall HPV prevalence in the head and neck ranged from 0 to $18 \%$ among men in Europe, and specific prevalence of all high-risk HPV types from 0 to $14.5 \%$. Due to the small number of European studies and the relatively small sample sizes, these results must be considered with caution. More robust data are available when worldwide studies are considered. Indeed, a systematic review of all published studies worldwide $(\mathrm{n}=18)$ that detected HPV DNA in the oral cavity of 4,070 cancerfree subjects found a pooled HPV prevalence (any type) of $4.5 \%$ (95\%CI: $3.9 \%-5.1 \%$ ); the prevalence of high-risk types was 3.5\% (95\%CI: 3.0\%-4.1\%) [84]. In a recent study of 1,680 healthy men from the United States, Mexico, and Brazil, HPV DNA was detected in the oral cavity of $4.0 \%$ (95\%CI: 3.1\%-5.0\%), and carcinogenic HPV DNA in 1.3\% (95\%CI: 0.8\%-2.0\%) of subjects [85].

\section{Anus}

The prevalence of anal HPV infection in men in European studies ranged between 15.3\% [49] and 94.1\% [50], but all these studies included presumably high-risk populations and there were no data on the prevalence of anal HPV infection in the general male population in Europe.

\section{Penis}

The prevalence of penile HPV infection in men in Europe ranged from $2.2 \%$ (95\%CI: $0.0 \%-6.4 \%$ ) [53] to $72.9 \%$ (95\%CI: $65.8 \%-79.3 \%$ ) [54]. The heterogeneity of the published data is partly due to the use of different sample techniques, detection methods, anatomical sites or specimens sampled, as well as study populations with different risk factors. The penis is made up of different types of body tissue, which differ in their susceptibility to HPV infection. Data from literature have indicated that the prepuce has the highest proportion of HPVpositive samples, though reports have also shown an increase in HPV DNA detection when multiple anatomical sites were sampled [86].

Most of the studies that evaluated the prevalence of HPV infection in anogenital sites included high-risk populations. Nevertheless, data from the United States have shown a very high prevalence of anogenital HPV infection $(65 \%)$ in population-based studies $[87,88]$. The incidence of new genital HPV infections in this population was 38.4 per 1,000 person months ( $95 \% \mathrm{CI}$ : 34.3 $43.0)$ in a recent study including men aged 18-70 years with a median duration of HPV infection of 7.52 months (95\%CI: 6.80-8.61) for any HPV infection and
12.19 months (95\%CI: 7.16-18.17) for infection with HPV16 [89].

In addition, a recent global review of the age-specific prevalence of HPV infection in men [86] identified 64 abstracts with data on genital HPV infection in men worldwide, including 38 from populations at high risk of HPV infection. The authors of the study concluded that the risk of HPV infection is generally high for most men in many geographical areas, with comparable prevalence in both low-risk (1-84\%) and high-risk populations (293\%).

Little is known about the natural history of HPV infection in men. Few studies have prospectively assessed HPV infection, and therefore few data are available on the incidence, acquisition and persistence of HPV infection in men. A recent review on HPV prevalence in men concluded that, in contrast to results for women, age-specific prevalence curves remained relatively flat with age, or declined only slightly with postpeak prevalence. Thus, men may potentially have more long-term persistent HPV infections, or a higher rate of re-infection [86].

\section{Comparison to the burden in women}

For comparison purposes, the methods described above were also used to estimate the epidemiological burden of HPV-related cancers and genital warts in women in Europe. Using our methods of estimation, a total of 32,562 cancer cases specifically due to HPV16/18 were expected to occur in women in Europe every year. The new annual number of cases of genital warts attributable to HPV6/11 in women in Europe was estimated to range between 288,959 and 388,873 .

A total of 48,059 HPV16/18-positive cancer cases were estimated to occur annually in Europe in both sexes, of which more than $30 \%$ occur in men (Table 8). Other than cervical cancer, 23,254 annual cases of which are estimated to be HPV16/18-positive, the estimated burden of cancer cases attributable to HPV is higher in men than in women, and is mainly driven by head and neck cancers.

The incidence of head and neck cancers attributable to HPV16/18 is five-fold higher in men $(12,707$ new cases yearly) than women (2,531 new cases yearly). In addition, new cases of genital warts attributable to HPV6/11 in both genders were estimated to range between 614,681 and 675,555 yearly in Europe, half of them affecting men.

\section{Impact of HPV vaccination}

The preliminary effects of HPV vaccination on genital warts and precancerous lesions have been reported from Australia, where a vaccination programme using the 
Table 8 The burden of new yearly human papillomavirus (HPV)16/18-related cancers in men vs. women in Europe ${ }^{a}$

\begin{tabular}{lll}
\hline Anatomical site (ICD-10 code) & $\begin{array}{l}\text { Men Number of new yearly cases (\% of } \\
\text { overall burden in both sexes) }\end{array}$ & $\begin{array}{l}\text { Women Number of new yearly cases (\% of } \\
\text { overall burden in both sexes) }\end{array}$ \\
\hline Cervix uteri (C53) & $0(\mathbf{0})$ & $23,254(48.4)$ \\
Head and neck (CO1-C02, C03-C06, C09, & $12,706(26.4)$ & $2,531(5.3)$ \\
C10, C12, C13, C14 and C32) & $1,700(3.5)$ & $2,929(6.1)$ \\
Anus (C21) & $0(\mathbf{0})$ & $2,702(5.6)$ \\
Vulva (C51) & $0(\mathbf{0})$ & $1,146(2.4)$ \\
Vagina (C52) & $1091(2.3)$ & $0(0)$ \\
Penis (C60) & $\underline{15,497(32.2)}$ & $32,562(67.8)$ \\
\hline Total &
\end{tabular}

ICD International Classification of Diseases

a 26 European countries

quadrivalent HPV vaccine was implemented. The data showed that in addition to a significant decline in the number of cases of genital warts and in the incidence of high-grade cervical abnormalities among young women in Australia, the number of cases of genital warts among heterosexual men also declined markedly [90].

\section{Limitations}

Our report has several limitations. A short-term prediction method was used to estimate the expected number of incident cancer cases in 2008 from the most recent data collected from 1998 to 2002. Therefore these predictions were accurate only if the disease rates remained stable over time. In the case of an increasing trend, they would slightly underestimate the expected number of cases, and the opposite would be true in the case of a decreasing trend.

As mentioned above, the CI5 database contains national cancer incidence rates for 17 European countries. For the remaining nine countries included in this report only regional incidence rates were available in the CI5 database. Although we assessed the geographical coverage and distribution of these regional registries, other non-controllable factors, like differences in alcohol and tobacco consumption, could vary and influence regional incidence rates. The results should thus be interpreted with particular caution.

The presence of HPV DNA is used to calculate the prevalence of HPV in a given population. However the mere presence of HPV is insufficient to prove causation, as the infection may be transient and not related to the carcinogenic process. Therefore our application of previously published HPV prevalence to an estimated number of new cancer cases may have yielded an overestimation of cases attributable to HPV infection. Finally, the prevalence of HPV16/18 co-infections has not been evaluated, thus summarising HPV16/18 prevalence may have led to an overestimation of the cancer burden attributable to these types.

Another limitation is the absence of sex-specific HPV prevalence data in anal and head and neck cancers.
Consequently, our report assumed that HPV prevalence is the same in both sexes. Currently, we have no reliable data that would confirm this hypothesis, and it seems to be inconsistent with the worldwide data from the metaanalysis by De Vuyst et al. [19], which showed a higher HPV prevalence in anal carcinoma among women (90.8\%) than men (74.9\%). To our knowledge, sex-specific data on HPV prevalence in head and neck cancers are lacking, and future research is needed.

We applied the same HPV prevalence to all European countries in this report. However, regional differences in HPV prevalence could exist, notably due to the fact that in some countries other non-HPV-related risk factors, i. e., tobacco or alcohol consumption may predominate. Furthermore, when type-specific HPV data for Europe was lacking, we used worldwide data, thus assuming that there is no difference in the HPV16/18 distribution between Europe and other parts of the world.

The method used to estimate the expected annual number of new genital wart cases attributable to HPV6/ 11 has also some limitations. We based our estimations on incidence data extracted from only two studies and only one of them was population-based [17]. In addition, due to the lack of data, it was not possible to extrapolate incidence data per age, but only by sex. However, there may be important differences in the age structure of European countries. Also, the incidence of genital warts throughout Europe may vary, due to regional differences in the prevalence of HPV infection and its underlying risk factors.

\section{Conclusions}

A total of 15,497 new cancer cases attributable to HPV16/18, and between 286,682 and 325,722 new cases of genital warts attributable to HPV6/11, were estimated to occur yearly in men in Europe.

The burden of HPV-related cancer in men is higher than generally perceived and is primarily driven by head and neck cancers. There is currently no routine screening for HPV-related cancers in men, and head and neck 
cancers in particular are associated with very high morbidity. In addition, there is some evidence of a steady rise of the incidence of HPV-related cancers and genital warts.

The high proportion of HPV-positive cancers attributable to HPV16/18, and of non-malignant diseases attributable to HPV6/11, underscores the potential to prevent the majority of HPV-related diseases among men through prophylactic vaccination with the quadrivalent HPV vaccine. Further research is needed to evaluate the efficacy of prophylactic HPV vaccines at noncervical sites in men and women.

\section{Abbreviations}

$\mathrm{Cl}$ : Confidence interval; Cl5: Cancer Incidence in Five Continents; CIN: Cervical intraepithelial neoplasia; GUM: Genitourinary medicine clinics; HPV: Human papillomavirus; IARC: International Agency for Research on Cancer; MSM: Men who have sex with men; STD: Sexually transmitted disease.

\section{Acknowledgements}

We thank Perrine Bertet for data extraction, Alfred Mahr and Sophie Carles for methodological support, and Trudy Perdrix-Thoma for editorial assistance.

\section{Author details}

'Department of Epidemiology, Sanofi Pasteur MSD, Lyon, France. ${ }^{2}$ Department of Oral Radiology and Pathology, Faculty of Medicine, Institute of Dentistry and MediCity Research Laboratory, Turku, Finland. ${ }^{3}$ Cancer Epidemiology Research Program, L'Hospitalet de Llobregat, Institut Català d'Oncologia (ICO)-IDIBELL, Catalonia, Spain. ${ }^{4}$ CIBER en Epidemiología y Salud Pública (CIBERESP), Barcelona, Spain.

\section{Authors' contributions}

$\mathrm{SH}$ contributed to the study design, literature research, data-analysis, interpretation of findings and drafting of the manuscript. SS contributed to the study design, interpretation of findings and critical editing of the manuscript. GDF contributed to the study design, interpretation of findings and critical editing of the manuscript. MB contributed to the data-analysis, interpretation of findings and critical editing of the manuscript. XC contributed to the study design, data-analysis, interpretation of findings and critical editing of the manuscript. All authors critically reviewed the manuscript and approved the final version.

\section{Competing interests}

SH and GDF are employed by Sanofi Pasteur MSD. SS has consulted Sanofi Pasteur MSD with regard to HPV in human diseases. MB has received occasional transport to attend scientific meetings from Glaxo Smith Kline. XC has received travel and speaker honoraria and investigator grants through ICO from Merck \& Co. Inc., Glaxo Smith Kline and Sanofi Pasteur MSD.

Received: 16 September 2011 Accepted: 20 January 2012

Published: 20 January 2012

\section{References}

1. Kjaer SK, Breugelmans G, Munk C, Junge J, Watson M, Iftner T: Populationbased prevalence, type- and age-specific distribution of HPV in women before introduction of an HPV-vaccination program in Denmark. Int J Cancer 2008, 123:1864-1870.

2. HPV and cervical cancer in the 2007 report. Vaccine 2007, 25 Suppl 3: C1-230, C1-230.

3. Arbyn M, Castellsague $X$, deSanjose S, Bruni L, Saraiya M, Bray F, et al: Worldwide burden of cervical cancer in 2008. Ann Oncol 2011, 22:2675-2686.

4. Kjaer SK, Tran TN, Sparen P, Tryggvadottir L, Munk C, Dasbach E, et al: The burden of genital warts: a study of nearly 70,000 women from the general female population in the 4 Nordic countries. J Infect Dis 2007 196:1447-1454.
5. Roteli-Martins CM, de Carvalho NS, Naud P, Teixeira J, Borba P, Derchain S, et al: Prevalence of human papillomavirus infection and associated risk factors in young women in Brazil, Canada, and the United States: a multicenter cross-sectional study. Int J Gynecol Pathol 2011, 30:173-184.

6. Ting J, Kruzikas DT, Smith JS: A global review of age-specific and overall prevalence of cervical lesions. Int J Gynecol Cancer 2010, 20:1244-1249.

7. Syrjanen K, Syrjanen S, Lamberg M, Pyrhonen S, Nuutinen J: Morphological and immunohistochemical evidence suggesting human papillomavirus (HPV) involvement in oral squamous cell carcinogenesis. Int J Oral Surg 1983, 12:418-424.

8. Human papillomaviruses. IARC Monogr Eval Carcinog Risks Hum 2007, 90:1-636, 1-636.

9. [http://monographs.iarc.fr/ENG/Monographs/vol100B/mono100B.pdf].

10. Aubin F, Pretet $J L$, Jacquard AC, Saunier M, Carcopino X, Jaroud F, et al: Human papillomavirus genotype distribution in external acuminata condylomata: a Large French National Study (EDiTH IV). Clin Infect Dis 2008, 47:610-615.

11. Donne AJ, Hampson L, Homer JJ, Hampson IN: The role of HPV type in Recurrent Respiratory Papillomatosis. Int J Pediatr Otorhinolaryngol 2010, 74:7-14.

12. Menton JF, Cremin SM, Canier L, Horgan M, Fanning LJ: Molecular epidemiology of sexually transmitted human papillomavirus in a self referred group of women in Ireland. Virol J 2009, 6:112, 112.

13. [http://epp.eurostat.ec.europa.eu/portal/page/portal/eurostat/home].

14. [http://www.iarc.fr]

15. Curado MP, Edwards B, Shin HR, Storm H, Ferlay J, Jeanue M, Boyle P: Comparability and quality of data. In Cancer Incidence in Five Containents. 2007, 9(Chapter 5)[http://www.iarc.fr/en/publications/pdfsonline/epi/sp160/Cl5vol9-5.pdf].

16. Desai S, Wetten S, Woodhall SC, Peters L, Hughes G, Soldan K: Genital warts and cost of care in England. Sex Transm Infect 2011

17. Kraut AA, Schink T, Schulze-Rath R, Mikolajczyk RT, Garbe E: Incidence of anogenital warts in Germany: a population-based cohort study. BMC Infect Dis 2010, 10:360.

18. Kreimer AR, Clifford GM, Boyle P, Franceschi S: Human papillomavirus types in head and neck squamous cell carcinomas worldwide: a systematic review. Cancer Epidemiol Biomarkers Prev 2005, 14:467-475.

19. De VH, Clifford GM, Nascimento MC, Madeleine MM, Franceschi S: Prevalence and type distribution of human papillomavirus in carcinoma and intraepithelial neoplasia of the vulva, vagina and anus: a metaanalysis. Int J Cancer 2009, 124:1626-1636.

20. Miralles-Guri C, Bruni L, Cubilla AL, Castellsague X, Bosch FX, de SS: Human papillomavirus prevalence and type distribution in penile carcinoma. $J$ Clin Pathol 2009, 62:870-878.

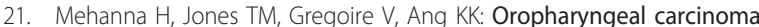
related to human papillomavirus. BMJ 2010, 340:C1439.

22. Hammarstedt L, Dahlstrand H, Lindquist D, Onelov L, Ryott M, Luo J, et al: The incidence of tonsillar cancer in Sweden is increasing. Acta Otolaryngol 2007, 127:988-992.

23. Nasman A, Attner P, Hammarstedt L, Du J, Eriksson M, Giraud G, et al: Incidence of human papillomavirus (HPV) positive tonsillar carcinoma in Stockholm, Sweden: an epidemic of viral-induced carcinoma? Int J Cancer 2009, 125:362-366.

24. Brewster $\mathrm{DH}$, Bhatti $\mathrm{LA}$ : Increasing incidence of squamous cell carcinoma of the anus in Scotland, 1975-2002. Br J Cancer 2006, 95:87-90.

25. Frisch $M$, Melbye $M$, Moller $H$ : Trends in incidence of anal cancer in Denmark. BMJ 1993, 306:419-422.

26. Nielsen A, Munk C, Kjaer SK: Trends in incidence of anal cancer and highgrade anal intraepithelial neoplasia in Denmark, 1978-2008. Int J Cancer 2011, 10.

27. Goldman S, Glimelius B, Nilsson B, Pahlman L: Incidence of anal epidermoid carcinoma in Sweden 1970-1984. Acta Chir Scand 1989, 155:191-197.

28. Van Lieshout A, Pronk A: [Increasing incidence of anal cancer in the Netherlands]. Ned Tijdschr Geneeskd 2010, 154:A1163.

29. Graafland NM, Verhoeven RH, Coebergh JW, Horenblas S: Incidence trends and survival of penile squamous cell carcinoma in the Netherlands. Int J Cancer 2011, 128:426-432.

30. Castellsague X, Cohet C, Puig-Tintore LM, Acebes LO, Salinas J, San MM, et al: Epidemiology and cost of treatment of genital warts in Spain. Eur J Public Health 2009, 19:106-110. 
31. Hippelainen M, Syrjanen S, Hippelainen M, Koskela H, Pulkkinen J, Saarikoski $S$, et al: Prevalence and risk factors of genital human papillomavirus (HPV) infections in healthy males: a study on Finnish conscripts. Sex Transm Dis 1993, 20:321-328.

32. Kataoka A, Claesson U, Hansson BG, Eriksson M, Lindh E: Human papillomavirus infection of the male diagnosed by Southern-blot hybridization and polymerase chain reaction: comparison between urethra samples and penile biopsy samples. J Med Virol 1991, 33:159-164.

33. Simms I, Fairley CK: Epidemiology of genital warts in England and Wales: 1971 to 1994. Genitourin Med 1997, 73:365-367.

34. Cassell JA, Mercer CH, Sutcliffe L, Petersen I, Islam A, Brook MG, et al: Trends in sexually transmitted infections in general practice 1990-2000: population based study using data from the UK general practice research database. BMJ 2006, 332:332-334.

35. Fenton KA, Korovessis C, Johnson AM, McCadden A, McManus S, Wellings $K$, et al: Sexual behaviour in Britain: reported sexually transmitted infections and prevalent genital Chlamydia trachomatis infection. Lancet 2001, 358:1851-1854.

36. Persson G, Andersson K, Krantz I: Symptomatic genital papillomavirus infection in a community. Incidence and clinical picture. Acta Obstet Gynecol Scand 1996, 75:287-290.

37. Bleeker MC, Hogewoning CJ, van den Brule AJ, Voorhorst FJ, Van Andel RE, Risse EK, et al: Penile lesions and human papillomavirus in male sexual partners of women with cervical intraepithelial neoplasia. J Am Acad Dermatol 2002, 47:351-357.

38. Kyriakis KP, Hadjivassiliou M, Paparizos VA, Riga P, Katsambas A: Determinants of genital wart case detection rates among STD clinic attendees in Athens, Greece. Int J Dermatol 2005, 44:650-653.

39. Svare El, Kjaer SK, Worm AM, Osterlind A, Meijer CJ, van den Brule AJ: Risk factors for genital HPV DNA in men resemble those found in women: study of male attendees at a Danish STD clinic. Sex Transm Infect 2002, 78:215-218.

40. van der Snoek EM, Niesters HG, Mulder PG, Van Doornum GJ, Osterhaus AD, van der Meijden Wl: Human papillomavirus infection in men who have sex with men participating in a Dutch gay-cohort study. Sex Transm Dis 2003, 30:639-644.

41. [http://www.hpa.org.uk/.

42. Lindeberg $H$, Elbrond O: Laryngeal papillomas: the epidemiology in a Danish subpopulation 1965-1984. Clin Otolaryngol Allied Sci 1990, 15:125-131.

43. Silverberg MJ, Thorsen $P$, Lindeberg H, Grant LA, Shah KV: Condyloma in pregnancy is strongly predictive of juvenile-onset recurrent respiratory papillomatosis. Obstet Gynecol 2003, 101:645-652.

44. Eike A, Buchwald C, Rolighed J, Lindeberg H: Human papillomavirus (HPV) is rarely present in normal oral and nasal mucosa. Clin Otolaryngol Allied Sci 1995, 20:171-173.

45. Van Doornum GJ, Hooykaas C, Juffermans LH, van der Lans SM, van der Linden MM, Coutinho RA, et al: Prevalence of human papillomavirus infections among heterosexual men and women with multiple sexual partners. J Med Virol 1992, 37:13-21.

46. Rintala M, Grenman S, Puranen M, Syrjanen S: Natural history of oral papillomavirus infections in spouses: a prospective Finnish HPV Family Study. J Clin Virol 2006, 35:89-94.

47. Kujan O, Desai M, Sargent A, Bailey A, Turner A, Sloan P: Potential applications of oral brush cytology with liquid-based technology: results from a cohort of normal oral mucosa. Oral Oncol 2006, 42:810-818.

48. Montaldo C, Mastinu A, Quartuccio M, Piras V, Denotti G, Pisano E, et al: Detection and genotyping of human papillomavirus DNA in samples from healthy Sardinian patients: a preliminary study. J Oral Pathol Med 2007, 36:482-487.

49. Van Doornum GJ, Prins M, Juffermans LH, Hooykaas C, van den Hoek JA, Coutinho RA, et al: Regional distribution and incidence of human papillomavirus infections among heterosexual men and women with multiple sexual partners: a prospective study. Genitourin Med 1994, 70:240-246.

50. Lowhagen GB, Bergbrant IM, Bergstrom T, Ryd W, Voog E: PCR detection of Epstein-Barr virus, herpes simplex virus and human papillomavirus from the anal mucosa in HIV-seropositive and HIV-seronegative homosexual men. Int J STD AIDS 1999, 10:615-618.

51. Piketty C, Darragh TM, Da CM, Bruneval P, Heard I, Kazatchkine MD, et al: High prevalence of anal human papillomavirus infection and anal cancer precursors among HIV-infected persons in the absence of anal intercourse. Ann Intern Med 2003, 138:453-459.

52. Sirera G, Videla S, Pinol M, Canadas MP, Llatjos M, Ballesteros AL, et al: High prevalence of human papillomavirus infection in the anus, penis and mouth in HIV-positive men. AIDS 2006, 20:1201-1204.

53. Aynaud O, Poveda JD, Huynh B, Guillemotonia A, Barrasso R: Frequency of herpes simplex virus, cytomegalovirus and human papillomavirus DNA in semen. Int J STD AIDS 2002, 13:547-550.

54. Bleeker MC, Hogewoning CJ, Berkhof J, Voorhorst FJ, Hesselink AT, van Diemen PM, et al: Concordance of specific human papillomavirus types in sex partners is more prevalent than would be expected by chance and is associated with increased viral loads. Clin Infect Dis 2005 41:612-620.

55. Barzon L, Militello V, Pagni S, Franchin E, Dal BF, Mengoli C, et al: Distribution of human papillomavirus types in the anogenital tract of females and males. J Med Virol 2010, 82:1424-1430.

56. Pierangeli A, Scagnolari C, Degener AM, Bucci M, Ciardi A, Riva E, et al: Type-specific human papillomavirus-DNA load in anal infection in HIVpositive men. AIDS 2008, 22:1929-1935.

57. Kjaer SK, Munk C, Winther JF, Jorgensen HO, Meijer CJ, van den Brule AJ: Acquisition and persistence of human papillomavirus infection in younger men: a prospective follow-up study among Danish soldiers. Cancer Epidemiol Biomarkers Prev 2005, 14:1528-1533.

58. Wikstrom A, Lidbrink P, Johansson B, von KG: Penile human papillomavirus carriage among men attending Swedish STD clinics. Int J STD AIDS 1991, 2:105-109.

59. Forslund $O$, Hansson BG, Rymark P, Bjerre B: Human papillomavirus DNA in urine samples compared with that in simultaneously collected urethra and cervix samples. J Clin Microbiol 1993, 31:1975-1979.

60. Franceschi S, Castellsague X, Dal ML, Smith JS, Plummer M, Ngelangel C, et al: Prevalence and determinants of human papillomavirus genital infection in men. Br J Cancer 2002, 86:705-711.

61. Hillman RJ, Ryait BK, Botcherby M, Taylor-Robinson D: Human papillomavirus DNA in the urogenital tracts of men with gonorrhoea, penile warts or genital dermatoses. Genitourin Med 1993, 69:187-192.

62. Aynaud O, Ionesco M, Barrasso R: Cytologic detection of human papillomavirus DNA in normal male urethral samples. Urology 2003, 61:1098-1101.

63. Giovannelli L, Migliore MC, Capra G, Caleca MP, Bellavia C, Perino A, et al: Penile, urethral, and seminal sampling for diagnosis of human papillomavirus infection in men. J Clin Microbiol 2007, 45:248-251.

64. Benevolo M, Mottolese M, Marandino F, Carosi M, Diodoro MG, Sentinelli S, et al: HPV prevalence among healthy Italian male sexual partners of women with cervical HPV infection. J Med Virol 2008, 80:1275-1281.

65. Bleeker MC, Hogewoning CJ, Voorhorst FJ, van den Brule AJ, Berkhof J, Hesselink AT, et al: HPV-associated flat penile lesions in men of a nonSTD hospital population: less frequent and smaller in size than in male sexual partners of women with CIN. Int J Cancer 2005, 113:36-41.

66. Castellsague X, Ghaffari A, Daniel RW, Bosch FX, Munoz N, Shah KV: Prevalence of penile human papillomavirus DNA in husbands of women with and without cervical neoplasia: a study in Spain and Colombia. J Infect Dis 1997, 176:353-361.

67. Bosch FX, Castellsague X, Munoz N, de SS, Ghaffari AM, Gonzalez LC, et al: Male sexual behavior and human papillomavirus DNA: key risk factors for cervical cancer in Spain. J Natl Cancer Inst 1996, 88:1060-1067.

68. Voog E, Ricksten A, Olofsson S, Ternesten A, Ryd W, Kjellstrom C, et al: Demonstration of Epstein-Barr virus DNA and human papillomavirus DNA in acetowhite lesions of the penile skin and the oral mucosa. Int $J$ STD AIDS 1997, 8:772-775.

69. Strand A, Rylander E, Evander M, Wadell G: Genital human papillomavirus infection among patients attending an STD clinic. Genitourin Med 1993, 69:446-449.

70. Lacey CJ, Lowndes CM, Shah KV: Chapter 4: Burden and management of non-cancerous HPV-related conditions: HPV-6/11 disease. Vaccine 2006, 24 Suppl 3:S3/35-41, S3-35-S3/41

71. Ramqvist $\mathrm{T}$, Dalianis $\mathrm{T}$ : An epidemic of oropharyngeal squamous cell carcinoma (OSCC) due to human papillomavirus (HPV) infection and aspects of treatment and prevention. Anticancer Res 2011, 31:1515-1519.

72. Attner P, Du J, Nasman A, Hammarstedt L, Ramqvist T, Lindholm J, et al: The role of human papillomavirus in the increased incidence of base of tongue cancer. Int J Cancer 2010, 126:2879-2884. 
73. Hobbs CG, Sterne JA, Bailey M, Heyderman RS, Birchall MA, Thomas SJ: Human papillomavirus and head and neck cancer: a systematic review and meta-analysis. Clin Otolaryngol 2006, 31:259-266.

74. Syrjanen S: HPV infections and tonsillar carcinoma. J Clin Pathol 2004, 57:449-455.

75. Colon-Lopez V, Ortiz AP, Palefsky J: Burden of human papillomavirus infection and related comorbidities in men: implications for research, disease prevention and health promotion among Hispanic men. $P R$ Health Sci J 2010, 29:232-240.

76. Palefsky JM, Rubin M: The epidemiology of anal human papillomavirus and related neoplasia. Obstet Gynecol Clin North Am 2009, 36:187-200.

77. Giuliano AR, Anic G, Nyitray AG: Epidemiology and pathology of HPV disease in males. Gynecol Oncol 2010, 117:S15-S19.

78. Parkin DM, Bray F: Chapter 2: The burden of HPV-related cancers. Vaccine 2006, 24 Suppl 3:S3/11-25, S3- 11-S3/25.

79. Backes DM, Kurman RJ, Pimenta JM, Smith JS: Systematic review of human papillomavirus prevalence in invasive penile cancer. Cancer Causes Control 2009, 20:449-457

80. Castellsague X, Albero G, Cleries R, Bosch FX: HPV and circumcision: a biased, inaccurate and misleading meta-analysis. J Infect 2007, 55:91-93.

81. [http://www.hpa.org.uk].

82. Maw RD, Reitano M, Roy M: An international survey of patients with genital warts: perceptions regarding treatment and impact on lifestyle. Int J STD AIDS 1998, 9:571-578.

83. Woodhall S, Ramsey T, Cai C, Crouch S, Jit M, Birks Y, et al: Estimation of the impact of genital warts on health-related quality of life. Sex Transm Infect 2008, 84:161-166.

84. Kreimer AR, Bhatia RK, Messeguer AL, Gonzalez P, Herrero R, Giuliano AR: Oral human papillomavirus in healthy individuals: a systematic review of the literature. Sex Transm Dis 2010, 37:386-391.

85. Kreimer AR, Villa A, Nyitray A, Abrahamsen ME, Papenfuss MR, Smith D, et al: The epidemiology of oral HPV infection among a multinational sample of healthy men. Cancer Epidemiol Biomarkers Prev 2010.

86. Smith JS, Gilbert PA, Melendy A, Rana RK, Pimenta JM: Age-specific prevalence of human papillomavirus infection in males: a global review. J Adolesc Health 2011, 48:540-552.

87. Giuliano AR, Lazcano-Ponce E, Villa LL, Flores R, Salmeron J, Lee JH, et al: The human papillomavirus infection in men study: human papillomavirus prevalence and type distribution among men residing in Brazil, Mexico, and the United States. Cancer Epidemiol Biomarkers Prev 2008, 17:2036-2043.

88. Nielson CM, Harris RB, Dunne EF, Abrahamsen M, Papenfuss MR, Flores R, et al: Risk factors for anogenital human papillomavirus infection in men. $\mathrm{J}$ Infect Dis 2007, 196:1137-1145.

89. Giuliano AR, Lee JH, Fulp W, Villa LL, Lazcano E, Papenfuss MR, et al: Incidence and clearance of genital human papillomavirus infection in men (HIM): a cohort study. Lancet 2011, 377:932-940.

90. Donovan B, Franklin N, Guy R, Grulich AE, Regan DG, Ali H, et al: Quadrivalent human papillomavirus vaccination and trends in genital warts in Australia: analysis of national sentinel surveillance data. Lancet Infect Dis 2011, 11:39-44.

\section{Pre-publication history}

The pre-publication history for this paper can be accessed here: http://www.biomedcentral.com/1471-2407/12/30/prepub

doi:10.1186/1471-2407-12-30

Cite this article as: Hartwig et al:: Estimation of the epidemiological burden of human papillomavirus-related cancers and non-malignant diseases in men in Europe: a review. BMC Cancer 2012 12:30.

\section{Submit your next manuscript to BioMed Central and take full advantage of:}

- Convenient online submission

- Thorough peer review

- No space constraints or color figure charges

- Immediate publication on acceptance

- Inclusion in PubMed, CAS, Scopus and Google Scholar

- Research which is freely available for redistribution

Submit your manuscript at www.biomedcentral.com/submit
Biomed Central 